\title{
LAW FIRM COPYING AND FAIR USE: AN EXAMINATION OF DIFFERENT PURPOSE AND FAIR USE MARKETS
}

\author{
D.R. JONES*
}

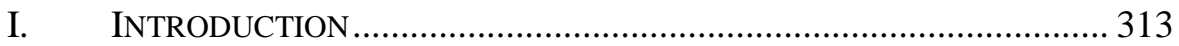

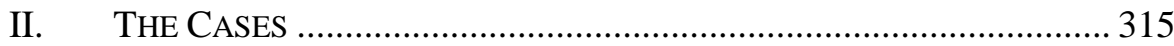

A. Procedural and Factual Background ................................... 315

B. The Decisions in Schwegman and Winstead .......................... 317

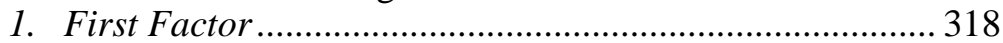

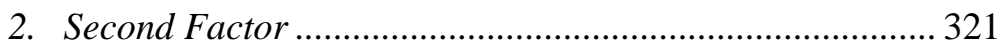

3. Third Factor ................................................................... 322

4. Fourth Factor....................................................................... 323

III. AN EXAMINATION OF THE DEFENDANT'S PURPOSE IN FAIR USE

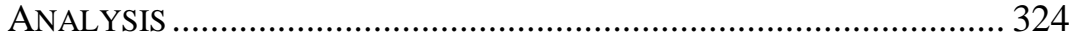

A. Evolution of Transformative Use: A Focus on Different

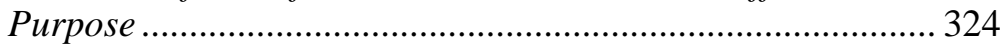

B. Purpose as Predictive ............................................................ 329

C. Purpose and Fourth Factor Analysis...................................... 333

D. Fair Use Markets .............................................................. 339

1. Definition of a Fair Use Market..................................... 339

2. Determination of a Fair Use Market ................................ 340

a. Considerations in the Immediate Context................... 343

b. Considerations in the Broader Context........................ 344

c. Summary: Determination of a Fair Use Market .......... 346

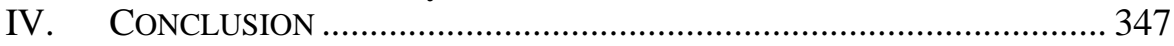

\section{INTRODUCTION}

The legal industry took note when publishers sued patent law firms for copyright infringement. These lawsuits focused on the law firms' alleged use of unlicensed copies of scholarly articles in patent application filings, including the use of copies for clients or internal review. The plaintiffs

* Assistant Professor of Law, the University of Memphis Cecil C. Humphreys School of Law. Thanks to the participants in the 2014 Works-in-Progress Intellectual Property Colloquium at Santa Clara University School of Law and participants in the 2014 Intellectual Property Scholars' Conference at UC Berkeley School of Law for their comments on earlier versions of this Article. Thanks to Rebecca Closner for her excellent research. Thanks also to Kate Schaffzin and Demetria Frank for their advice regarding evidence. 
claimed the loss of licensing fees due to the defendants' copying. The defendants successfully argued that the use of the copies in connection with the patent application process was fair use, even though there was a means of collecting fees for the use.

The doctrine of fair use is a powerful exception to the rights of copyright holders. Under this exception, copyrighted works can be used without the copyright holder's permission. Section 107 codifies the fair use doctrine. ${ }^{1}$ Fair use analysis primarily focuses on the four factors listed in that section. ${ }^{2}$ The first factor, the "purpose and character of the use," ${ }^{3}$ is a critical part of overall fair use analysis. This Article uses the patent application cases as a vehicle to review the use of purpose in fair use analysis. It advocates that the study of the character and purpose of a use should include a deeper examination of the policies and societal interests underlying the use. This broader consideration is especially important if a plaintiff asserts the presence of a ready market for the payment of fees for use of a copyrighted work.

Part II of this Article summarizes the decisions in two patent application cases in which judges rendered opinions. Part III examines the focus on the defendant's purpose in fair use analysis. It uses the decisions in the lawsuits against the patent firms as a vehicle for this examination. It describes how these decisions fit well into a line of cases in which the determination of transformative use based on different purpose has evolved from the Campbell v. Acuff-Rose Music, Inc. ${ }^{4}$ decision over twenty years ago to more recent court decisions. Part II also notes the continuing uncertainty in the identification of transformative use. It suggests that a more predictable outcome is available if a defendant can identify that a use is within a category of uses that courts regularly determine support fair use. As an example, the patent application cases fit within the favored category of uses of copyrighted works in quasi-judicial and judicial proceedings. This categorization of a use, however, may not be adequate to address market effect if the plaintiff claims the loss of licensing fees.

Scholars have expressed concerns that the availability of a ready market for licensing eclipses fair use analysis under the fourth factor. Part III explores the determination of a fair use market as a way to support the unlicensed use of copyrighted works, although a ready market exists for the payment of fees. The patent application cases and the larger category of use of copyrighted works in legal proceedings offer an excellent illustration of the analysis necessary to determine a fair use market. This analysis builds

1. 17 U.S.C. $\S 107$ (2012).

2. See infra text accompanying notes 30-37.

3. $\S 107(1)$

4. Campbell v. Acuff-Rose Music, Inc., 510 U.S. 569 (1994). 
on Professor Wendy Gordon's discussion and refinement of the concept of fair use markets. ${ }^{5}$ This concept provides a unique means of identifying when a defendant can use a copyrighted work without permission, even though there is a method available for fee payments.

\section{THE CASES}

\section{A. Procedural and Factual Background}

In 2012, publishers filed lawsuits alleging copyright infringement against four law firms. ${ }^{6}$ In their initial complaints, the plaintiffs argued that the law firms had not obtained their permission before filing copies of copyrighted articles in patent applications. ${ }^{7}$ The plaintiffs voluntarily dismissed the case against one of the firms after that case settled. ${ }^{8}$ The defendants in the remaining three lawsuits denied the allegations of infringement and raised several defenses, including fair use. ${ }^{9}$ The United States Patent and Trademark Office (PTO) intervened as a defendant in these three lawsuits. ${ }^{10}$

5. See infra text accompanying notes 190-203.

6. The plaintiff-publishers were the American Institute of Physics and John Wiley \& Sons, Ltd. (the plaintiffs). The four defendant law firms were as follows: McDonnell Boehnen Hulbert \& Berghoff LLP (Chicago, Illinois); Winstead PC (Dallas, Texas); Hovey Williams LLP (Topeka, Kansas); and Schwegman Lundberg \& Woessner, P.A. (Minneapolis, Minnesota) (the defendants). All four law firms engage in patent prosecution.

7. Plaintiff's Original Complaint at 1, 3, 4, Am. Inst. of Physics v. Winstead PC, Civil Action No. 3:12-CV-1230-M, 2013 WL 6242843 (N.D. Tex. Dec. 3, 2013) [hereinafter Winstead Complaint]; Complaint at 1, 3, 4, Am. Inst. of Physics v. Schwegman, Lundberg \& Woessner, P.A., Civil No. 12-528 (RHK/JJK), 2013 WL 4666330 (D. Minn. Aug. 30, 2013) [hereinafter Schwegman Complaint]; Complaint at 1, 3, 4, John Wiley \& Sons, Inc. v. Hovey Williams LLP, 5:12-cv-04041-RDR-KGS (D. Kan. Apr. 20, 2012) [hereinafter Hovey Williams Complaint]; Complaint at 1, 3, 4, John Wiley \& Sons, Ltd. v. McDonnell Boehnen Hulbert \& Berghoff LLP, No. 1:12-cv-01446 (N.D. Ill. Feb. 29, 2012) [hereinafter Boehnen Complaint]. The plaintiffs also alleged that the defendants had made infringing "internal" copies of copyrighted articles in connection with the patent application filings. Winstead Complaint, supra, at 4; Schwegman Complaint, supra, at 4; Hovey Williams Complaint, supra, at 4; Boehnen Complaint, supra, at 4.

8. Notice of Voluntary Dismissal at 1 , John Wiley \& Sons, Inc. v. Hovey Williams LLP, No. 5:12-cv-04041-RDR-KGS (D. Kan. June 22, 2012).

9. Answer at 1, 4, Am. Inst. of Physics v. Schwegman, Lundberg \& Woessner, P.A., Civil No. 12-528 (RHK/JJK), 2013 WL 4666330 (D. Minn. Aug. 30, 2013); Answer at 3, 9, John Wiley \& Sons, Ltd. v. McDonnell Boehnen Hulbert \& Berghoff LLP, No. 1:12-cv-01446 (N.D. Ill. Apr. 12, 2012); see Am. Inst. of Physics v. Winstead PC, Civil Action No. 3:12-CV-1230-M, 2013 WL 6242843, at *1 (N.D. Tex. Dec. 3, 2013).

10. Motion to Intervene at 1, Am. Inst. of Physics v. Winstead PC, No. 3:12-CV-1230-M, 2013 WL 6242843 (N.D. Tex. Dec. 3, 2013); Motion to Intervene at 1, Am. Inst. of Physics v. Schwegman, Lundberg \& Woessner, P.A., Civil No. 12-528 (RHK/JJK), 2013 WL 4666330 (D. Minn. Aug. 30, 2013); Motion to Intervene at 1, John Wiley \& Sons, Ltd. v. McDonnell Boehnen Hulbert \& Berghoff LLP, No. 1:12-cv-01446 (N.D. Ill. June 12, 2012). The PTO intervened because of the possible effects a decision could have on the patent process. It asserted that the copying and use of articles in patent proceedings constituted fair use. Memorandum of Law in 
These cases were brought in the context of the patent application process. An inventor may obtain a patent by submitting a patent application to the PTO. ${ }^{11}$ The PTO's examination process includes a determination of the patentability of the invention. ${ }^{12}$ As part of this process, the examiner considers "prior art."13 Prior art can include scholarly scientific and technical articles (i.e., non-patent literature (NPL)), as well as previously issued patents. ${ }^{14}$ An examiner searches for prior art as part of the review, ${ }^{15}$ but an applicant also provides prior art. ${ }^{16}$ A patent applicant has "a duty to disclose... all information known to that individual to be material to patentability." 17

To comply with this duty of disclosure, the defendants filed scholarly articles as part of the patent applications. ${ }^{18}$ The plaintiffs initially alleged that the filing of NPL without permission constituted infringement. ${ }^{19}$ The plaintiffs later amended their complaints to exclude the filed NPL, as well

Support of USPTO's Motion for Judgment on the Pleadings or Partial Summary Judgment on Its Fair Use Defense \& Counterclaim at 6-7, Am. Inst. of Physics v. Winstead PC, No. 3:12-CV01230-M, 2013 WL 6242843 (N.D. Tex. Dec. 3, 2013); Memorandum of Law in Support of USPTO's Motion for Summary Judgment on Its Fair Use Defense \& Counterclaim at 2, Am. Inst. of Physics v. Schwegman, Lundberg \& Woessner, P.A., Civil No. 12-528 (RHK/JJK), 2013 WL 4666330 (D. Minn. Aug. 30, 2013). In January 2012, the PTO issued a memorandum discussing the application of fair use in the patent examination process. Memorandum from Bernard J. Knight, Jr., Gen. Counsel, U.S. Patent \& Trademark Office, at 2 (Jan. 19, 2012).

11. 35 U.S.C. $\S \S 101,111$ (2012). Under Article I, Section 8 of the United States Constitution, Congress has the power "to promote the Progress of Science and useful Arts, by securing for limited Times to Authors and Inventors the exclusive Right to their respective Writings and Discoveries.” Pursuant to this power, Congress has promulgated patent laws that are codified in 35 U.S.C. $\S \S 1-390$. Rules and regulations governing patents are set forth in title 37 of the Code of Federal Regulations.

12. 37 C.F.R. § 1.104(a) (2013); see also 35 U.S.C. §§ 102, 103 (setting forth the conditions for patentability).

13. 37 C.F.R. § 1.104(a)(1).

14. See 35 U.S.C. § 102(a)(1).

15. 37 C.F.R. § 1.104(a)(1).

16. The applicant can provide an information disclosure statement along with the application. This statement includes copies of any information submitted for consideration. See 37 C.F.R. § 1.98(d). The PTO encourages applicants "to file . . . information disclosure statement[s]." Id. § 1.51(d). In addition to the information disclosure statement, the applicant must file copies of publications that are material to the claim of patentability. See id. § 1.98(a)(2)(ii), (iv).

17. Id. This disclosure helps the PTO become "aware of and evaluate[] the teachings of all information material to patentability." Id. This disclosure is part of a "duty of candor and good faith.” Id. The applicant's attorneys and any other "individual associated with the filing and prosecution of a patent application” also have this duty. Id. § 1.56(a).

18. See Winstead's Reply in Support of Motion to Dismiss Amended Complaint at 3, Am. Inst. of Physics v. Winstead PC, No. 3:12-CV-01230-M, 2013 WL 6242843 (N.D. Tex. Dec. 3, 2013); Schwegman Lundberg \& Woessner, P.A.'s Memorandum of Law in Support of Its Motion for Summary Judgment at 4, Am. Inst. of Physics v. Schwegman, Lundberg \& Woessner, P.A., Civil No. 12-528 (RHK/JJK), 2013 WL 4666330 (D. Minn. Aug. 30, 2013).

19. Winstead Complaint, supra note 7, at 1; Schwegman Complaint, supra note 7, at 1; Boehnen Complaint, supra note 7, at 1. 
as one copy for archival purposes. ${ }^{20}$ The amended complaints focused on other copies, such as copies provided to clients. ${ }^{21}$ While the plaintiffs' amended complaints excluded filings with the PTO and archival copies, the judges in Schwegman and Winstead still considered these copies in their review of the issues. ${ }^{22}$

The Schwegman and Winstead lawsuits resulted in district court decisions for the defendants. ${ }^{23}$ The plaintiffs filed an appeal in the Schwegman case ${ }^{24}$ but later dismissed the appeal. ${ }^{25}$ They also filed a stipulated motion for dismissal with prejudice in the Winstead case. ${ }^{26}$ In addition, the plaintiffs filed for dismissal in the third case, which was still in the discovery phase. ${ }^{27}$ This Article focuses on the Schwegman and Winstead cases.

\section{B. The Decisions in Schwegman and Winstead}

In Schwegman and Winstead, both judges ${ }^{28}$ determined that the defendants' copying constituted fair use as a matter of law and granted summary judgment for the defendants. ${ }^{29}$ Subpart II(B) of this Article

20. See Plaintiffs' Amended Complaint at 1, Am. Inst. of Physics v. Winstead PC, Civil Action No. 3:12-CV-01230-M, 2013 WL 6242843 (N.D. Tex. Dec. 3, 2013) [hereinafter Winstead Amended Complaint]; Plaintiffs' Amended Complaint at 1-2, Am. Inst. of Physics v. Schwegman, Lundberg \& Woessner, P.A., Civil No. 12-528 (RHK/JJK), 2013 WL 4666330 (D. Minn. Aug. 30, 2013) [hereinafter Schwegman Amended Complaint]; Amended Complaint at 1-2, John Wiley \& Sons, Ltd. v. McDonnell Boehnen Hulbert \& Berghoff LLP, No. 1:12-cv-01446 (N.D. Ill. July 13, 2012) [hereinafter Boehnen Amended Complaint].

21. Winstead Amended Complaint, supra note 20, at 1, 4; Schwegman Amended Complaint, supra note 20, at 1, 5; Boehnen Amended Complaint, supra note 20, at 1, 5.

22. See infra note 29.

23. Am. Inst. of Physics v. Winstead PC, Civil Action No. 3:12-cv-1230-M, 2013 WL 6242843, at *14 (N.D. Tex. Dec. 3, 2013); Am. Inst. of Physics v. Schwegman Lundberg \& Woessner, P.A., Civil No. 12-528 (RHK/JJK), at 2 (D. Minn. July 30, 2013), adopted by 2013 WL 4666330 (D. Minn. Aug. 30, 2013).

24. Letter from the Clerk of the Court at 1, Am. Inst. of Physics v. Schwegman, Lundberg \& Woessner, P.A., No. 13-3351 (8th Cir. Oct. 28, 2013), ECF No. 1.

25. Stipulation of Parties to Dismiss Appeal Pursuant to FED. R. APP. P. 42(a) at 1-2, Am. Inst. of Physics v. Schwegman, Lundberg \& Woessner, P.A., Civil No. 12-528 (RHK/JJK), 2013 WL 4666330 (D. Minn. Aug. 30, 2013).

26. Stipulated Motion for Dismissal with Prejudice at 1 , Am. Inst. of Physics v. Winstead PC, Civil Action No. 3:12-CV-1230-M, 2013 WL 6242843 (N.D. Tex. Dec. 3, 2013).

27. Plaintiffs' Motion for Voluntary Dismissal with Prejudice Pursuant to Federal Rule of Civil Procedure 41(A)(2) at 1, John Wiley \& Sons, Ltd. v. McDonnell Boehnen Hulbert \& Berghoff LLP, No. 1:12-cv-01446 (N.D. Ill. Mar. 5, 2014).

28. The judge in Schwegman was Magistrate Judge Jeffrey J. Keyes. Am. Inst. of Physics v. Schwegman Lundberg \& Woessner, P.A., Civil No. 12-528 (RHK/JJK), at 1 (D. Minn. July 30, 2013), adopted by 2013 WL 4666330 (D. Minn. Aug. 30, 2013). The judge in Winstead was Judge Barbara M.G. Lynn. Am. Inst. of Physics v. Winstead PC, Civil Action No. 3:12-cv-1230-M, 2013 WL 6242843, at *1 (N.D. Tex. Dec. 3, 2013).

29. Winstead, 2013 WL 6242843, at *14; Schwegman, at 2. In Schwegman, the district court adopted the magistrate judge's report and recommendation after a de novo review. Am. Inst. 
reviews the judges' fair use analysis in Schwegman and Winstead. Under the 1976 Copyright Act, ${ }^{30}$ copyright holders have numerous rights, including the right "to reproduce the copyrighted work in copies or phonorecords." 31 "[F]air use is an affirmative defense" to infringement of a copyright holder's rights in a work. ${ }^{32}$ Congress codified the long-standing judicial doctrine of fair use ${ }^{33}$ in $\S 107$ of the Copyright Act of $1976 .{ }^{34} \mathrm{~A}$ court's determination of fair use "calls for [a] case-by-case analysis." 35 In its analysis, the court must consider and "weigh[ ] together" ${ }^{36}$ the nonexclusive four factors listed in $\S 107 .{ }^{37}$

\section{First Factor}

The judges in both Schwegman and Winstead determined that the first factor favored fair use. ${ }^{38}$ The first factor focuses on "the purpose and

of Physics v. Schwegman Lundberg \& Woessner, P.A., Civil No. 12-528 (RHK/JJK), 2013 WL 4666330, at *1-2 (D. Minn. Aug. 30, 2013). In their amended complaints, the plaintiffs in these cases dropped allegations concerning copies that the law firms had filed with the PTO and copies made for archival purposes. Winstead, 2013 WL 6242843, at *2; Schwegman, at 4-5.

In Schwegman, Judge Keyes discussed the disagreement as to whether the plaintiffs had conceded that the making of these copies was fair use. Schwegman, at 5-6 n.3. He concluded the plaintiffs had not conceded this fact. Id. at 6 n.3. Even though the plaintiffs had dropped their claims relating to the copies for the PTO filing and archival purposes, the defendants' use of copies in the patent application process was still relevant. See id. They could not "dissociate" the copying from the law firm's patent prosecution practice. Id. In Winstead, however, Judge Lynn stated the plaintiffs had admitted that the making of the copies for the PTO filing and archival purposes was fair use. Winstead, 2013 WL 6242843, at *6.

30. Copyright Act of 1976, Pub. L. 94-553, 90 Stat. 2541.

31. 17 U.S.C. § 106(1) (2012).

32. Campbell v. Acuff-Rose Music, Inc., 510 U.S. 569, 590 (1994).

33. See 4 William F. PATRY, PATRY ON COPYRIGHT § 10:2, at 10-12 (2007); see also H.R. REP. No. 94-1476, at 65 (1976), reprinted in 1976 U.S.C.C.A.N. 5659, 5678 ("The judicial doctrine of fair use [is] one of the most important and well-established limitations on the exclusive right of copyright owners ....”).

34. 17 U.S.C. $\S 107$. Section 107 provides that "the fair use of a copyrighted work . . is not an infringement of copyright.” Id.

35. Campbell, 510 U.S. at 577; see also H.R. REP. No. 94-1476, at 66 ("Beyond a very broad statutory explanation of what fair use is and some of the criteria applicable to it, the courts must be free to adapt the doctrine to particular situations on a case-by-case basis.”).

36. Campbell, 510 U.S. at 578.

37. The four factors listed in $\S 107$ are as follows:

(1) the purpose and character of the use, including whether such use is of a commercial nature or is for nonprofit educational purposes;

(2) the nature of the copyrighted work;

(3) the amount and substantiality of the portion used in relation to the copyrighted work as a whole; and work

(4) the effect of the use upon the potential market for or value of the copyrighted

17 U.S.C. § 107(1)-(4).

38. Am. Inst. of Physics v. Winstead PC, Civil Action No. 3:12-cv-1230-M, 2013 WL 6242843, at *9 (N.D. Tex. Dec. 3, 2013); Am. Inst. of Physics v. Schwegman Lundberg \& 
character of the use." 39 The Supreme Court in Campbell v. Acuff-Rose Music, Inc. established that under the first factor, a court determines whether the defendant's work is "transformative" by "add[ing] something new, with a further purpose or different character," or whether it "merely supersede[s] ... the original." 40 The transformative nature of a work can diminish the importance of countervailing factors. ${ }^{41}$ Both judges concluded that the defendants' copying constituted a "transformative use" of the articles, ${ }^{42}$ even though the defendants made exact copies. ${ }^{43}$ Judge Keyes noted in Schwegman that the "lack of alteration may make the label 'transformative use' a messy fit," but a finding of fair use would still be appropriate if "the use's purpose and character differs from the object of the original., ${ }^{44}$

The judges determined in each case that the defendants used the copies for a different intrinsic purpose than the original-namely, to review the articles for information relevant to patentability and to provide that information as evidence in the context of the patent application process. ${ }^{45} \mathrm{In}$ contrast, the original purpose for the publication of the articles was to provide the scientific community with information about current developments. ${ }^{46}$ Judge Lynn in Winstead noted that the defendants were not reading the articles to learn, but rather to identify and provide evidence of the existence of the information in order to obtain "a quasi-judicial decision." "77 Judge Keyes in Schwegman discussed cases in which the courts had determined that the use of copyrighted materials as evidence in judicial proceedings constituted fair use. ${ }^{48}$ He equated the defendants' use of the articles as evidence in the patent process with the use of copyrighted materials in those cases. ${ }^{49}$

Judge Keyes determined that the defendants' use of internal copies fit within "determining how best to represent... clients' interests in quasi-

Woessner, P.A., Civil No. 12-528 (RHK/JJK), at 30 (D. Minn. July 30, 2013), adopted by 2013 WL 4666330 (D. Minn. Aug. 30, 2013).

39. $\quad 17$ U.S.C. § 107(1).

40. Campbell, 510 U.S. at 578-79 (second alteration in original) (quoting Folsom v. Marsh, 9 F. Cas. 342, 348 (Cir. Ct. D. Mass. 1849)) (internal quotation marks omitted).

41. See id.

42. See Winstead, 2013 WL 6242843, at *11; Schwegman, at 23-24, 27.

43. Winstead, 2013 WL 6242843, at *10; Schwegman, at 30.

44. Schwegman, at 24-25; see also 17 U.S.C. § 107.

45. Winstead, 2013 WL 6242843, at *5; Schwegman, at 22-23, 26-27.

46. Winstead, 2013 WL 6242843, at *5; Schwegman, at 23. Judge Keyes in Schwegman also discussed that the defendants were a different audience for the articles than the audience for the articles at the time of publication. Schwegman, at 10-12. This difference indicated how the defendants' usage of the articles differed from the usage of original readers of the articles. Id.

47. Winstead, 2013 WL 6242843, at *5.

48. Schwegman, at 25-26.

49. Id. at 26 . 
judicial proceedings." 50 Judge Lynn also determined that internal copies made for attorneys to review for filing with the PTO and copies of articles attached to PTO filings and sent to clients were "indistinguishable" from copies filed with the PTO and therefore covered as a fair use. ${ }^{51}$

The analysis of the "purpose and character of the use" includes a determination of "whether such [a] use is of a commercial nature or is for nonprofit educational purposes." 52 The plaintiffs in the Schwegman and Winstead cases argued that the defendant law firms were for-profit businesses that were obtaining a commercial benefit from the copied articles. ${ }^{53}$ Relying on American Geophysical Union v. Texaco Inc., ${ }^{54}$ the plaintiffs contended that the defendants' commercial use of the articles negated a finding of fair use under the first factor. ${ }^{55}$ Rejecting the plaintiffs' argument, Judge Keyes in Schwegman simply stated: "This case is not Texaco."56 Judge Lynn in Winstead similarly stated that "Texaco [is] inapposite." 57 Both judges distinguished the facts of Texaco. Judge Keyes noted there was no evidence that the defendants were "superseding the original purpose of the [a]rticles" by "maintaining mini-research libraries"

50. Id.

51. Winstead, 2013 WL 6242843, at *6. In footnote four of her opinion, Judge Lynn described some of the copies that the defendants made. Copies of articles included the following:

[O]ne email from a Winstead legal assistant to three client contacts, a Winstead attorney and a Winstead in-firm patent agent, forwarding a USPTO non-final office action on a patent as to which the article was included as an attachment; four emails forwarding the previous e-mail; one email from a Winstead in-firm patent agent to three clients and a Winstead attorney containing a draft submission to the USPTO to which the article was attached.

Id. at $* 2$ n. 4 (emphasis added).

52. 17 U.S.C. § 107(1) (2012).

53. Winstead Amended Complaint, supra note 20, at 4; Schwegman Amended Complaint, supra note 20 , at 5 .

54. Am. Geophysical Union v. Texaco Inc., 60 F.3d 913 (2d Cir. 1994). In Texaco, the plaintiff-publisher claimed that Texaco infringed the publisher's copyrights when Texaco scientists made copies of scholarly articles for personal files. Id. at 914. The scientists copied the articles for possible later use in their research. Texaco claimed that the copying constituted fair use. Id. at 914-15. The Second Circuit rejected the fair use defense. Id. at 931. The court of appeals determined that the weight of the first factor was against the defendant since researchers were making use of the copied articles for the same purpose as the original. See id. at 919-20. The researchers were maintaining copies in their personal libraries in lieu of the company purchasing additional subscriptions. Id. at 919 .

55. Memorandum of Plaintiffs in Opposition to the Motion of Defendant Schwegman, Lundberg \& Woessner, P.A. to Dismiss the Complaint at 1, Am. Inst. of Physics v. Schwegman, Lundberg \& Woessner, P.A., Civil No. 12-528 (RHK/JJK), 2013 WL 4666330 (D. Minn. Aug. 30, 2013); see Winstead, 2013 WL 6242843, at *7; Am. Inst. of Physics v. Schwegman Lundberg \& Woessner, P.A., Civil No. 12-528 (RHK/JJK), at 28 (D. Minn. July 30, 2013), adopted by 2013 WL 4666330 (D. Minn. Aug. 30, 2013).

56. Schwegman, at 29.

57. Winstead, 2013 WL 6242843, at *7. 
in lieu of paying for subscriptions. ${ }^{58}$ Judge Lynn also determined that the defendants in Winstead did not maintain mini-libraries. ${ }^{59}$ Furthermore, she noted that the defendants' purpose in using the articles was different from the original, unlike the scientists' use of articles in Texaсо. ${ }^{60}$

Judge Lynn rejected the plaintiffs' contention that since the defendants charged an hourly rate for reading the articles, they had gained a commercial benefit from those articles. ${ }^{61}$ The Winstead opinion also addressed the plaintiffs' argument that the law firm was a "commercial enterprise" that was reaping a profit by charging clients for making copies. ${ }^{62}$ Judge Lynn determined that the law firm, if it charged clients for copies, charged only enough to recoup costs and did not make a profit. ${ }^{63}$ Judge Lynn concluded that "[t]he commercialism inquiry does not disfavor [d] efendants' fair use defense." 64

\section{Second Factor}

In each case, the judge quickly determined that the second factor-the "nature of the copyrighted work" ${ }^{65}$ - favored fair use. ${ }^{66}$ In Winstead, Judge Lynn agreed with the defendants that the copied articles contained "factual

58. Schwegman, at 29-30. Judge Keyes, in a footnote, distinguished the situation in which a law firm was making copies of a copyrighted work and distributing them to each lawyer in the firm. Id. at $30 \mathrm{n} .10$. In that case, the firm would be "systematically avoiding paying licensing fees by multiplying copies for its employees to use copyrighted materials exactly how they were intended to be used." Id.

59. Winstead, 2013 WL 6242843, at *7 ("Unlike Texaco, Defendants do not maintain a library of copyrighted works or save copies of NPL to individual hard drives, but instead isolate NPL to individual client files, and keep NPL photocopies or digital copies solely in client files. There is no way to search for previously used NPL in Winstead's computer network, nor is there a physical library of NPL articles.”).

60. Id.

61. Id. The court specified that the defendants were charging for the time spent and were not obtaining a commercial benefit from the copies themselves. Id. ("The Court finds Texaco inapplicable here, where the monetary gain received by the Defendants for reading an article is generated from the use of the attorneys' own time and not the content of the article itself.”).

62. Id. Judge Lynn distinguished this situation from Princeton University Press $v$. Michigan Document Services, Inc., 99 F.3d 1381 (6th Cir. 1996) (en banc), in which the defendant made a profit from selling copies and was therefore unable to maintain a fair use defense. Winstead, 2013 WL 6242843, at *7 (citing Princeton Univ. Press, 99 F.3d at 1383).

63. Winstead, 2013 WL 6242843, at*7. It was not relevant that companies in the business of making copies could charge lower rates, thus suggesting that the firm's charges resulted in a profit. See id.

64. Id. at *8. "Even if [the d] efendants' use of [the p]laintiffs' works did occur in a commercial context, that fact is not determinative.” Id. (citing Campbell v. Acuff-Rose Music, Inc., 510 U.S. 569, 584 (1994)).

65. 17 U.S.C. § 107(2) (2012).

66. One scholar has noted that "[d]espite the confusion surrounding its sister factors, courts address [the second] factor with remarkable efficiency and frugality.” Robert Kasunic, Is That All There Is? Reflections on the Nature of the Second Fair Use Factor, 31 COLUM. J.L. \& ARTS 529, 529 (2008). 
and scientific information" that was subject to less protection. ${ }^{67}$ Although the copied articles contained "protectable, expressive content," Judge Lynn distinguished those articles from works such as poems or stories, which "are less likely to fall under the fair use defense."68 The second factor in Winstead therefore favored a finding of fair use. ${ }^{69}$ Likewise, Judge Keyes in Schwegman characterized the copied articles as "factual or informational.",70 He concluded that the copied works fell "a bit farther from the core of intended copyright protection than do other, more 'creative' works," and thus the second factor favored fair use. ${ }^{71}$

\section{Third Factor}

Both judges linked the amount of permitted copying under the third factor to the "purpose and character of the use." 72 The third factor focuses on "the amount and substantiality of the portion [of the work] used in relation to the copyrighted work as a whole." ${ }^{73}$ In both cases, the defendants copied entire articles. ${ }^{74}$ Judge Keyes noted the "new and different purpose" that the defendants' copying served and concluded that the third factor favored fair use. ${ }^{75}$ Copying entire articles "was essential" because the defendants needed to review the entire articles for relevant information that they had to disclose in the application process. ${ }^{76}$ Judge Lynn also determined that the defendants' need to fulfill ethical obligations under the PTO's disclosure requirements mitigated the negative impact of copying entire works. ${ }^{77}$ She was less willing, however, to declare the third factor in

67. Winstead, 2013 WL 6242843, at *9. Judge Lynn noted that “[t]he law generally recognizes a greater need to disseminate factual works than works of fiction or fantasy.” Id. (quoting Harper \& Row Publishers, Inc. v. Nation Enters., 471 U.S. 539, 563 (1985)).

68. Id.

69. Id

70. Am. Inst. of Physics v. Schwegman Lundberg \& Woessner, P.A., Civil No. 12-528 (RHK/JJK), at 37 (D. Minn. July 30, 2013), adopted by 2013 WL 4666330 (D. Minn. Aug. 30, 2013). Judge Keyes noted that "[t]he scope of fair use is greater when 'informational' as opposed to more 'creative' works are involved.” Id. at 36 (quoting Hustler Magazine, Inc. v. Moral Majority, Inc., 796 F.2d 1148, 1153-54 (9th Cir. 1986)).

71. Id. at 37.

72. Both judges noted that the amount of permitted copying under the third factor depends on the "purpose and character of the use." Winstead, 2013 WL 6242843, at *10 (quoting Campbell v. Acuff-Rose Music, Inc., 510 U.S. 569, 586-87 (1994)); Schwegman, at 37-38 (quoting Castle Rock Entm’t, Inc. v. Carol Publ’g Grp., Inc., 150 F.3d 132, 144 (2d Cir. 1998)).

73. 17 U.S.C. § 107(3) (2012).

74. Winstead, 2013 WL 6242843, at *10 ("Defendants copy NPL in their entirety.”); Schwegman, at 38 ("There is no dispute that [defendant] copied the [a]rticles in their entirety.").

75. Schwegman, at 38 .

76. Id.

77. Winstead, 2013 WL 6242843, at *10. 
favor of fair use. Instead, she concluded that "the third factor [was] neutral or weigh[ed] only slightly against a finding of fair use."

\section{Fourth Factor}

The judges in both Schwegman and Winstead determined that the fourth factor ${ }^{79}$ weighed in favor of fair use ${ }^{80}$ Both judges concluded that the defendants' copying did not usurp or adversely affect the market for the original articles. ${ }^{81}$ Judge Keyes observed there was no evidence that the defendants' failure to pay a fee for use of the articles would "disincentivize the authors ... from creating the work in the first place and distributing it to the traditional audience for the work or that this use would reduce demand for the original work." 82

The plaintiffs argued that they had lost licensing revenues from the copies. ${ }^{83}$ Judge Keyes acknowledged that the plaintiffs might have lost revenue if the defendants did not obtain licenses. ${ }^{84}$ He held, however, that "the fact that the [plaintiffs] may have lost licensing revenue... is not determinative and does not create a fact issue for trial." ${ }^{85} \mathrm{He}$ again distinguished the facts of Texaco by reiterating that the defendants' use of the copies in Schwegman did not supersede the original use of the articles, which was the case in Texaco. ${ }^{86}$ In Winstead, Judge Lynn also rejected the plaintiffs' argument that their loss of licensing fees supported a denial of fair use. $^{87}$ Judge Lynn stated that the public benefit of "minimiz[ing] excessive costs in patent applications and maximiz[ing] the accuracy of the patent process" outweighed any gain to the plaintiffs from potential fees. ${ }^{88}$

78. Id

79. The fourth factor focuses on "the effect of the use upon the potential market for or value of the copyrighted work.” 17 U.S.C. § 107(4) (2012).

80. Winstead, 2013 WL 6242843, at *10; Schwegman, at 36; see also text accompanying notes 182-189 and 239-242 infra for additional discussion.

81. Winstead, 2013 WL 6242843, at *11 (“[Defendants'] actions have no significant impact on the market for Plaintiffs' original articles.”); Schwegman, at 31 (“[Plaintiffs] present no evidence that the patent lawyers' use of the scientific [a]rticles to meet their obligations to disclose prior art to the PTO adversely affects the traditional target market for these [a]rticles .....”). Judge Lynn noted that most of the articles were older articles with a diminished value and copies were not distributed to the public. Winstead, 2013 WL 6242843, at*11.

82. Schwegman, at 31 ; see also id. at $40-41$.

83. Id. at 31-32. The plaintiffs noted that licensing was available and other law firms had obtained licenses. Id. at 32.

84. Id. at 32 .

85. Id. at 33 .

86. Id.

87. Am. Inst. of Physics v. Winstead PC, Civil Action No. 3:12-cv-1230-M, 2013 WL 6242843, at *11 (N.D. Tex. Dec. 3, 2013).

88. Id. at $* 12$. 


\section{AN EXAMINATION OF THE DEFENDANT's PURPOSE IN FAIR USE ANALYSIS}

Part III of this Article examines the role of purpose in fair use analysis, the need for an enhanced analysis of purpose, and the application of an enhanced analysis of purpose in addressing market effect. While the lawsuits against the patent law firms have ended, these cases provide a vehicle for an examination of the key role the defendant's purpose plays in fair use analysis. The defendant's purpose for using a work is critical in determining the transformativeness of a defendant's use. Certain types of uses regularly support findings of fair use due to their special underlying purposes. Ultimately, a defendant's purpose influences the four-factor analysis of the market effect of the defendant's use and the outcome of a determination of fair use.

The examination of purpose in this Part focuses on how the underlying reasoning for a defendant's use can support a finding of fair use. This deeper analysis goes beyond simply identifying a defendant's purpose and categorizing that purpose; it can be a critical influence in the ultimate determination of fair use.

\section{A. Evolution of Transformative Use: A Focus on Different Purpose}

The determinations of transformative use in Schwegman and Winstead fit within an evolving focus on and interpretation of transformative use that has developed over the twenty years since the Supreme Court's decision in Campbell. This focus concentrates on the defendant's purpose in using the work. The Supreme Court's 1994 adoption of Judge Pierre Leval's transformative use analysis ${ }^{89}$ altered courts' overall treatment of $\S 107$ 's four factors in fair use cases. ${ }^{90}$ Studies of fair use decisions have determined that transformative use "overwhelmingly drives fair use analysis in the courts today." 91 The Court's discussion of transformative use did not

89. In Campbell, the Supreme Court quoted Judge Leval's influential article, Toward a Fair Use Standard, in its discussion. Campbell v. Acuff-Rose Music, Inc., 510 U.S. 569, 579 (1994) (quoting Pierre N. Leval, Toward a Fair Use Standard, 103 HARV. L. REV. 1105, 1111 (1990)). The Court stated that in addressing the first factor, the "central purpose" is to determine "whether the new work merely 'supersede[s] the objects' of the original creation, or instead adds something new, with a further purpose or different character, altering the first with new expression, meaning, or message; ... . in other words, whether and to what extent the new work is 'transformative."' Id. (citations omitted) (quoting Leval, supra, at 1111).

90. See Neil Weinstock Netanel, Making Sense of Fair Use, 15 LEWIS \& CLARK L. REV. 715,719 (2011).

91. Id. at 734, 736, 746; see also Michael D. Murray, What Is Transformative? An Explanatory Synthesis of the Convergence of Transformation and Predominant Purpose in Copyright Fair Use Law, 11 CHI.-KenT J. InTELL. PROP. 260, 261 (2012) (“The transformative test . . . has become the defining standard for fair use.”); Matthew Sag, Predicting Fair Use, 73 
provide a clear definition, ${ }^{92}$ leaving the task to interpretation in future cases. Studies focused on courts' application of transformative use analysis have determined that in later cases, courts have predominately focused on the purpose of the defendant's work rather than the content. ${ }^{93}$ It is a different purpose, "not new expressive content," that is crucial. ${ }^{94}$ Further, there are a significant number of cases finding a transformative use when the defendant copied the entire work without alteration and used it for a different purpose. $^{95}$

Recent Second Circuit cases demonstrate the continuing focus on the defendant's purpose as a key part of the transformative use analysis. In 2014, the Second Circuit held, in two very different cases, that the defendant's use of an unaltered work was transformative because the use served a different purpose from the original use. In Swatch Group Management Services, Ltd. v. Bloomberg, L.P., ${ }^{96}$ Bloomberg distributed to

Oніо Sт. L.J. 47, 84 (2012) (“[E]vidence ... confirms the centrality of transformative use.”). This dominance arose after 2005. Netanel, supra note 90, at 734. Initially, commentators grappled with the lack of clarity in decisions following Campbell that applied the transformative use analysis. Matthew D. Bunker, Transforming the News: Copyright and Fair Use in News-Related Contexts, 52 J. COPYRIGHT SOC'Y U.S.A. 309, 326 (2005) (“Criteria for transformativeness seem underdeveloped, if not absent.”); Diane Leenheer Zimmerman, The More Things Change, the Less They Seem "Transformed": Some Reflections on Fair Use, 46 J. COPYRIGHT SOC’Y U.S.A. 251, 251 (1998) ("[T]he use of the term [transformative] seemed governed by no set meaning, and the conclusions reached about transformativeness-its presence or absence-were wildly divergent.”).

Commentators on overall fair use analysis also found that decisions were unpredictable. David Nimmer, "Fairest of Them All" and Other Fairy Tales of Fair Use, 66 LAW \& CONTEMP. PROBS., 263, 280 (2003) ("[H]ad Congress legislated a dartboard rather than the particular four fair use factors . . . it appears that the upshot would be the same.”). Later empirical studies demonstrated that fair use analysis is not "arbitrary and ad hoc." Netanel, supra note 90, at 718. These later studies were: (1) Barton Beebe, An Empirical Study of U.S. Copyright Fair Use Opinions, 1978-2005, 156 U. PENN. L. ReV. 549 (2008); (2) Netanel, supra note 90; (3) Sag, supra note 91; and (4) Paula Samuelson, Unbundling Fair Uses, 77 FORDHAM L. REV. 2537 (2009).

92. Netanel, supra note 90, at 746. In particular, it was unclear whether to be transformative, a work should have a different purpose from the original, a different character, or both. See id. at 746-47; Rebecca Tushnet, Copy This Essay: How Fair Use Doctrine Harms Free Speech and How Copying Serves It, 114 YALE L.J. 535, 546 (2004) (expressing concerns that transformative use required "new, critical meaning").

93. See Murray, supra note 91, at 261; Netanel, supra note 90, at 747; R. Anthony Reese, Transformativeness and the Derivative Work Right, 31 COLUM. J.L. \& ARTS 467, 485 (2008).

94. Netanel, supra note 90, at 747.

95. See id.; Reese, supra note 93, at 485.

96. Swatch Grp. Mgmt. Servs. Ltd. v. Bloomberg L.P. (Swatch Grp. II), 756 F.3d 73 (2d Cir.), amending and superseding (Swatch Grp. I), 742 F.3d 17 (2d Cir. 2014). In the earlier opinion, the court noted that uses may not be transformative but can still be fair use. Swatch Grp. I, 742 F.3d at 28. The court in Swatch Grp. I did not discuss a different purpose as a basis for determining transformative use. See id. at 28-30. The May 30th opinion contains substantial additional discussion of the defendant's purpose and the transformativeness of this purpose. See Swatch Grp. II, 756 F.3d at 84-86. 
its subscribers an unauthorized copy of a recorded Swatch conference call involving company executives and investment analysts. ${ }^{97}$ Bloomberg distributed an exact copy of the recording without any added commentary or alterations. ${ }^{98}$ The Second Circuit determined that Bloomberg's use and distribution of the recording were fair use. ${ }^{99}$ The focus of the court's firstfactor analysis was on the different message and purpose of Bloomberg's dissemination. ${ }^{100}$ The court decided that Bloomberg's use of the work was transformative without changes or added commentary solely due to its different purpose. ${ }^{101}$

Later in 2014 the Second Circuit again focused on the defendant's purpose in a case involving a very different type of use than that in Swatch Group v. Bloomberg. In Authors Guild, Inc. v. HathiTrust, the Second Circuit ruled that the copying of copyrighted works for a searchable, fulltext database and for providing digital access to the "print disabled"102 constituted fair use. ${ }^{103}$ In its first-factor analysis, the court emphasized that "a transformative work is one that serves a new and different function from the original work and is not a substitute for it." 104 The court determined that the creation of the database was a "quintessentially transformative use." 105 The defendants' purpose was to create a searchable database while the authors' purpose was to provide access to the content of the works. ${ }^{106}$ The

97. Swatch Grp. II, 756 F.3d at 78-79. The call was to discuss company earnings and was by invitation only. Media representatives were not invited to join the call. Id. at 22 .

98. Id. at 78, 83.

99. Id. at 92 .

100. Id. at 84-85. Bloomberg disseminated the recording to evidence "newsworthy information of what Swatch Group executives had said.” Id. at 85. Swatch used the call to assure analysts of the reliability of its previously announced earnings. Id. The Second Circuit contrasted Bloomberg's message ("This is what they said") with Swatch's message ("This is what you should believe”). Id. Bloomberg's different purpose gave its "use at least an arguably transformative character." Id. The court also noted that Bloomberg's use of the recording was "in the nature of news reporting" and "served the important public purpose" of circulating valuable financial information. Id. at 82, 92.

101. Id. at 84. The court of appeals cited A.V. ex rel. Vanderhye v. iParadigms, LLC, 562 F.3d 630, 639 (4th Cir. 2009), and Perfect 10, Inc. v. Amazon.com, Inc., 508 F.3d 1146, 1165 (9th Cir. 2007). The courts in these decisions determined that the defendants' uses were transformative despite the lack of alteration of the work. See infra discussion accompanying notes 117-122.

102. "Print disabled" is a term that refers to individuals with "any disability that prevents [them] from effectively reading printed material.” Authors Guild, Inc. v. HathiTrust, 755 F.3d 87, 91 (2d Cir. 2014).

103. Id. at 105.

104. Id. at 96. The court of appeals disagreed with the district court that simply providing "[a]dded value or utility" would constitute a transformative use. Id.

105. Id. at 97 .

106. See id. The defendants scanned entire works to build a searchable database. Id. at 9092. Although the entire work was in the database, HathiTrust's search engine did not provide any access to the text of a work unless the copyright holder had given permission. Id. at 91. There was no evidence that the authors created the works for "the purpose of enabling text searches." Id. at 97. The district court had determined that the purpose of the database was "entirely different" 
court concluded that "the full-text search function does not 'supersede[ ] the objects [or purposes] of the original creation."”107 Notably, the court added "or purposes" to the quote from Campbell that focuses on substitution for the work itself. ${ }^{108}$ While the court found that the creation of the full-text database was a "transformative use," it rejected the district court's decision that providing access to the print disabled was transformative. ${ }^{109}$ The Second Circuit's reasoned that providing access to the print disabled simply expanded the number of possible users for the same purpose that the authors created the original works. ${ }^{110}$ Converting text to a more accessible format did not change the purpose. Although providing access to the print disabled was not a transformative use, it was still a valid purpose that favored fair use. ${ }^{111}$ The Second Circuit found the defendants' purpose to be a critical element in its first-factor analysis. ${ }^{112}$

In Swatch Group and HathiTrust, the Second Circuit affirmed that a use could be transformative without any changes in the original work if the defendant's purpose is different from the original purpose. In both cases the court grounded its analysis in its previous decisions and other circuit court opinions. One of the decisions it cited was Bill Graham Archives v. Dorling Kindersley Ltd. ${ }^{113}$ In that case, the Second Circuit held that the use of miniaturized, unaltered images of posters in a biographical work was "separate and distinct from the original ... purpose for which the images were created." "114 This "transformatively different" use supported a finding of fair use under the first-factor analysis. ${ }^{115}$ The Second Circuit in Swatch Group and HathiTrust also enumerated cases in other circuits that had

from the original purpose for the authors' works. Authors Guild, Inc. v. HathiTrust, 902 F. Supp. 2d 445, 460 (S.D.N.Y. 2012), aff'd in part, vacated in part, 755 F.3d 87 (2d Cir. 2014) (“[T]he purpose [was] superior search capabilities rather than actual access to copyrighted material.”).

107. Authors Guild, 755 F.3d at 97 (alterations in original) (quoting Campbell v. Acuff-Rose Music, Inc., 510 U.S. 569, 579 (1994)).

108. See id. The Supreme Court in Campbell was quoting Folsom v. Marsh, 9 F. Cas. 342, 348 (Cir. Ct. D. Mass. 1841). Campbell, 510 U.S. at 579.

109. Authors Guild, 755 F.3d at 101.

110. Id.

111. Id. at 102. The court of appeals noted that the legislative history of $\S 107$ expressly identified the making of free copies for the print disabled as an example of fair use. Id. (citing H.R. REP. No. 94-1476, at 73 (1976), reprinted in 1976 U.S.C.C.A.N. 5659, 5686)).

112. Id. at 97. While the defendants did not change the original works, the court of appeals noted that the search capabilities in the database added "something new" with a different purpose and character. Id. The focus of the decision, however, was on the defendants' purpose.

113. Id. at 97-100; Bill Graham Archives v. Dorling Kindersley Ltd., 448 F.3d 605 (2d Cir. 2006).

114. Bill Graham Archives, 448 F.3d at 610.

115. Id. at 612 . 
followed this transformative use analysis. ${ }^{116}$ These references show the continuing development and support for finding transformative use based solely on a different purpose.

All of the cases that the Second Circuit referenced in Swatch Group and HathiTrust rely on the transformative use analysis in Campbell, ${ }^{117}$ but further clarify its application. The Fourth Circuit summarized the analysis in A.V. ex rel. Vanderhye v. iParadigms, LLC this way: "The use of a copyrighted work need not alter or augment the work to be transformative in nature. Rather, it can be transformative in function or purpose without altering or actually adding to the original work." ${ }^{118}$ The Ninth Circuit relied on this same analysis in finding transformative use in two cases. Perfect 10, Inc. v. Amazon.com, Inc. and Kelly v. Arriba Soft Corp., both involved the use of low-resolution thumbnail versions of copyrighted images as Internet search tools. ${ }^{119}$ The Ninth Circuit held in both cases that the use of the images was transformative, even though there were no alterations in those images. ${ }^{120}$ In Kelly, the Ninth Circuit held that the defendant's use was transformative because the defendant had "created a different purpose for the images" and was "not superseding” the plaintiff's use. ${ }^{121}$ In Perfect 10, the Ninth Circuit followed its reasoning in Kelly, reiterating that "even making an exact copy of a work may be transformative so long as the copy serves a different function than the original work." 122

116. Authors Guild, 755 F.3d at 97-98; Swatch Grp. Mgmt. Servs. Ltd. v. Bloomberg L.P. (Swatch Grp. II), 756 F.3d 73, 84(2d Cir.), amending and superseding (Swatch Grp. I), 742 F.3d 17 (2d Cir. 2014).

117. Campbell v. Acuff-Rose Music, Inc., 510 U.S. 569, 579 (1994).

118. A.V. ex rel. Vanderhye v. iParadigms, LLC, 562 F.3d 630, 639 (4th Cir. 2009). In iParadigms, the defendant used the full text of student papers to create a searchable database for determining plagiarism. Id. at 641-42. There was no alteration in the papers. Id. at 639. Users of the database could not see the papers themselves but could see matches with language in works they submitted for comparison. See id. at 634. The court determined that the defendant's use of the works was transformative because it "had an entirely different function and purpose than the original works.” Id. at 639-40.

119. Perfect 10, Inc. v. Amazon.com, Inc., 508 F.3d 1146, 1165 (9th Cir. 2007); Kelly v. Arriba Soft Corp., 336 F.3d 811, 819 (9th Cir. 2003).

120. Perfect 10, 508 F.3d at 1165; Kelly, 336 F.3d at 819.

121. Kelly, 336 F.3d at 819. The defendant's use of the image was to "improve access to [information] on the [I]nternet.” Id. at 818. The plaintiff's purpose was “artistic expression.” Id. at 819.

122. Perfect 10, 508 F.3d at 1165 (citing Kelly, 336 F.3d at 818-19). In Kelly and Perfect 10, the Ninth Circuit relied on a First Circuit case, Núñez v. Caribbean Int'l News Corp., 235 F.3d 18 (1st Cir. 2000). In Núñez, the defendant used unaltered photos of a female model as the focus of a newspaper story about the photos. Id. at 21. The First Circuit determined that the use of the photos was transformative because the defendant's use (print photos in newspaper) was different from the original purpose for the photos (use in a modeling portfolio). Id. at 23. The Second Circuit cited Núnez in both Swatch Group and Authors Guild. Swatch Grp. Mgmt. Servs. Ltd. v. Bloomberg L.P. (Swatch Grp. II), 756 F.3d 73, 84 (2d Cir.) (citing Núñez, 235 F.3d at 22-23), amending and 
Courts within the Second Circuit as well as other circuit courts have consistently demonstrated the willingness to designate use of unaltered works as transformative when the defendant's purpose is different from the original. ${ }^{123}$ These cases substantiate the trend identified in studies by Professor Reese and Professor Netanel that the key factor in determining transformative use is "whether the use is for a different purpose than that for which the copyrighted work was created," not the addition of "new expressive content." ${ }^{124}$

\section{B. Purpose as Predictive}

Commentators have suggested that there needs to be further guidance as to whether a particular purpose will qualify as transformative in order to support a finding of fair use under the first factor. ${ }^{125}$ The goal is greater predictability regarding the applicability of fair use in a given situation. ${ }^{126}$ Reliance on the designation of a use as transformative and basing this designation on a difference in purpose can be problematic. In some cases, there remains a difference between a transformative use that requires an alteration in the work and a use that is simply different. Despite the focus on purpose and the acceptance of fair use, in the absence of alteration there

superseding (Swatch Grp. I), 742 F.3d 17 (2d Cir. 2014); Authors Guild, Inc. v. HathiTrust, 755 F.3d 87, 95 (2d Cir. 2014) (citing Núñez, 235 F.3d at 25).

123. Two additional decisions fit with these cases, although they include more discussion of additions to the copied works. The U.S. District Court for the Southern District of New York found transformative use in two cases in which the defendants had a different purpose for their use and also added "something new" to the copied works. In Authors Guild, Inc. v. Google Inc., the district court held that Google's digitization of entire books to create a search tool was "highly transformative.” Authors Guild, Inc. v. Google Inc., 954 F. Supp. 2d 282, 291 (S.D.N.Y. 2013). Google's use of these unaltered works was to create "pointers" to direct users to books. Id. This was a different purpose than the purpose for the creation of the original works. Id. The court cited Perfect 10, Kelly and Bill Graham Archives in its discussion of transformative use. Id.

In another case, the U.S. District Court for the Southern District of New York determined that the inclusion of digitized legal briefs, memoranda, and documents in searchable databases was fair use. White v. West Publ'g Corp., No. 12 CIV. 1340 JSR, 2014 WL 3057885, at *1, *4 (S.D.N.Y. July 3, 2014). The court determined that the database providers' use of the digitized documents was transformative. $I d$. at $* 2$. The database providers used the documents to provide "an interactive legal research tool." Id. This purpose was different from the reason for the original creation of the documents, which was to provide legal services. Id. The defendants also " “add[ed] something new"” to the documents through coding, linking, and other modifications. Id.

124. Netanel, supra note 90, at 747; Reese, supra note 93, at 485. Professor Netanel notes that adding or modifying expressive content can be helpful, but it is a different purpose that is critical to the determination of transformative use. Netanel, supra note 90, at 747.

125. Netanel, supra note 90, at 749-50; Reese, supra note 93, at 494-95.

126. See Netanel, supra note 90, at 718. Greater predictability could help reduce what Professor Gibson refers to as "doctrinal feedback." James Gibson, Risk Aversion and Rights Accretion in Intellectual Property Law, 116 YALE L.J. 882, 898-900 (2007). Continuing uncertainty as to whether certain uses of copyrighted works would qualify as fair use can result in risk-averse users paying for licenses they do not need. See id. at 899-900. 
remains an impression that a defendant's use of a work should involve some change in the original. ${ }^{127}$

Professor Netanel discussed that determining whether a use is transformative requires comparing the plaintiff's purpose for the original work and the defendant's purpose in using the work. ${ }^{128}$ He submits that the focus should be on the difference in purpose and not on the nature "of the defendant's use in and of itself." 129 Yet, as he notes, "there seem to be certain types of uses that correlate positively with a finding of fair use.”130 This correlation indicates that the specific nature of the defendant's use is relevant to predicting a court's analysis in a fair use case. Professor Samuelson classified specific uses into "policy-relevant clusters"131 and determined that "it is generally possible to predict whether a use is . . fair or unfair" by analyzing the use "in light of cases previously decided in the same policy cluster." ${ }^{132}$ Identifying a defendant's use as part of a common category of uses can, at the least, support an argument that a court should treat the defendant's use the same. ${ }^{133}$ This categorization could also help

127. See, e.g., Images Audio Visual Prods., Inc. v. Perini Bldg. Co., 91 F. Supp. 2d 1075, 1081 (E.D. Mich. 2000) (determining that the use of a work was not transformative and then discussing whether the defendant used the work for a different purpose). Some courts seem hesitant about applying the transformative label to a use involving no alteration or addition. In Schwegman, Judge Keyes maintained that the first factor favors fair use because of the defendants' different purpose for using the works, even though the "lack of alteration may make the label 'transformative use' a messy fit . . . since the 'transformative use' label is most apt when a secondary work . . . actually alters the content.” Am. Inst. of Physics v. Schwegman, Lundberg \& Woessner, P.A., Civil No. 12-528 (RHK/JJK), at 24 (D. Minn. July 30, 2013) (emphasis added), adopted by 2013 WL 4666330 (D. Minn. Aug. 30, 2013). The word “transform” suggests a change in character of the work rather than use. In Swatch Group v. Bloomberg, the Second Circuit discussed that the defendant's unaltered use had "at least an arguably transformative character" and concluded that the use was fair "regardless of how transformative" it was. Swatch Grp. Mgmt. Servs. Ltd. v. Bloomberg L.P. (Swatch Grp. II), 756 F.3d 73, 85 (2d Cir.), amending and superseding (Swatch Grp. I), 742 F.3d 17 (2d Cir. 2014). This ambivalent language indicates a hesitancy to designate as transformative those uses that do not include an alteration of a work.

128. Netanel, supra note 90 , at 749-50.

129. Id.

130. Id. at 750. A closer look at the defendants' purposes in the transformative use cases validates the observation that certain purposes favor a finding of fair use. For example, HathiTrust, Perfect 10, Kelly, iParadigms, Authors Guild v. Google, and White v. West Publishing involved digitizing copyrighted works to create searchable databases. See discussion supra notes 119, 123 and accompanying text; A.V. ex rel. Vanderhye v. iParadigms, LLC, 562 F.3d 630, 63435 (4th Cir. 2009); Perfect 10, Inc. v. Amazon.com, Inc., 508 F.3d 1146, 1157 (9th Cir. 2007); Kelly v. Arriba Soft Corp., 336 F.3d 811, 815, 815-16 (9th Cir. 2003). The Second Circuit concluded in HathiTrust that "the creation of a full-text searchable database is a quintessentially transformative use.” Authors Guild, Inc. v. HathiTrust, 755 F.3d 87, 97 (2d Cir. 2014).

131. Samuelson, supra note 91, at 2541. See id. at 2544-46 for a summary of the clusters.

132. Id. at 2542. In discussing the clusters, Professor Samuelson identified "policies underlying modern fair use law" that support the uses within each policy cluster. Id. at 2541-42.

133. Paul Goldstein, Fair Use in Context, 31 ColuM. J.L. \& ARTS 433, 442-43 (2008); see also Michael J. Madison, A Pattern-Oriented Approach to Fair Use, 45 WM. \& MARY L. ReV. 1525, 1667 (2004). 
overcome uncertainty regarding whether a use involving no alterations in the work is transformative. ${ }^{134}$

As an illustration of fair use and categorization, in Schwegman and Winstead, the defendants' use fit within a recognized category meriting fair use treatment. The judges in those cases determined that the defendants' use of the copyrighted works was for the purpose of providing evidence in a quasi-judicial proceeding. ${ }^{135}$ Courts have consistently recognized fair use when defendants used copyrighted works without permission in connection with judicial and quasi-judicial proceedings. ${ }^{136}$ This usage includes submitting a copyrighted work as evidence ${ }^{137}$ and using a copyrighted work for trial-related purposes. ${ }^{138}$ Many of the cases do not provide analysis but

134. Professor Samuelson refers to use of a work without an alteration in the work as an "orthogonal use[]" and separates these uses from truly transformative uses. Samuelson, supra note 91, at 2544 n.40, 2593. Professor Samuelson suggests that "[a]lthough Campbell defines 'transformative' in a way that encompasses uses for different purposes, copyright law will be more comprehensible and coherent if iterative copying for orthogonal purposes is distinguished from truly transformative uses of prior works.” Id. at 2557.

135. See discussion supra notes 45-50 and accompanying text.

136. Netanel, supra note 90, at 750; Samuelson, supra note 91, at 2592-94; see also Madison, supra note 133, at 1659 (offering examples of uses "in the context of rules regulating litigation and trial" that were recognized as fair). Congress identified the "reproduction of a work in . . . judicial proceedings" as an example of "the sort of activities the courts might regard as fair use under the circumstances.” H.R. REP. NO. 94-1476, at 65 (1976), reprinted in 1976 U.S.C.C.A.N. 5659, 5678; see also ALAN LATMAN, COPYRIGHT LAW REVISION, STUDIES PREPARED FOR THE SUBCOMM. ON PATENTS, TRADEMARKS, \& COPYRIGHTS OF THE S. COMM. ON THE JUdiCIARY, 86TH CONG., STUDY NO. 14: FAIR USE OF COPYRIGHTED WORKS 13 (Comm. Print 1960) ("It would seem that great latitude would be accorded [use of copyrighted material in connection with pending litigation].”); 4 MELVILLE B. NIMMER \& DAVID NIMMER, NIMMER ON COPYRIGHT § 13.05[D][2], at 13-230.14 (2014) (“Works are customarily reproduced in various types of judicial proceedings ... . and it seems inconceivable that any court would hold such reproduction to constitute infringement either by the government or by the individual parties responsible for offering the work in evidence.”).

The exceptions to this recognition occur when the defendant uses a copyrighted work that the plaintiff prepared for the litigation. E.g., Images Audio Visual Prods., Inc. v. Perini Bldg. Co., 91 F. Supp. 2d 1075, 1083 (E.D. Mich. 2000) (noting that the defendant made extra copies of photographs that the plaintiff created specifically for arbitration proceedings). In these situations, the purpose is no longer different because the plaintiff created the original work for the same purpose as the defendant's use: to serve as evidence.

137. E.g., Bond v. Blum, 317 F.3d 385, 389-390 (4th Cir. 2003) (involving a manuscript of biographical work submitted in child-custody proceeding as evidence regarding author's fitness for custody); Jartech, Inc. v. Clancy, 666 F.2d 403, 405, 407 (9th Cir. 1982) (involving surreptitiously obtained excerpts of films used as evidence in nuisance proceeding).

138. E.g., Religious Tech. Ctr. v. Wollersheim, 971 F.2d 364, 367 (9th Cir. 1992) (per curiam) (involving an attorney who used copied documents to prepare witnesses); Sturgis v. Hurst, No. 07-11301, 2007 WL 4247634, at *2 (E.D. Mich. Dec. 4, 2007) (involving a defendant who used excerpts from plaintiff's work for cross-examination); Healthcare Advocates, Inc. v. Harding, Earley, Follmer \& Frailey, 497 F. Supp. 2d 627, 636, 639 (E.D. Pa. 2007) (involving copies of archived screenshots of earlier version of website at issue in litigation used to prepare for trial); Lucent Info. Mgmt., Inc. v. Lucent Techs., Inc., 5 F. Supp. 2d 238, 242-43 (D. Del. 
simply state, with little or no citation, that the defendant's unauthorized use of a work in a judicial proceeding is fair use. ${ }^{139}$ The opinions that provide fair use analysis in these cases focus on the purpose for the use of the copyrighted works in proceedings. ${ }^{140}$ The defendant's use of the works in these cases is evidentiary. ${ }^{141}$ The courts focus on how this use differs from the original use for the work. ${ }^{142}$

These cases illustrate how establishing that a defendant's use is within a recognized category can greatly strengthen a finding of fair use, even if the transformativeness of the use is unclear. Many of these cases, however, hinge simply on the identification of purpose and not on a deeper analysis of that purpose. Determining whether the defendant's purpose fits within an identified group of uses that have supported fair use in the past can bolster a claim for fair use. It is essential, however, to do more than just identify whether a purpose fits within a group and whether it is different from the plaintiff's purpose. Identifying a use within a "policy cluster," to use Professor Samuelson's categorization, is a start. ${ }^{143}$ Delving deeper into the underlying reasoning and policy for a purpose and why that purpose is within a policy cluster "provides another dimension" that "sharpens

1998) (involving use of copyrighted letter to conduct surveys regarding possible trademark confusion), aff'd, 186 F.3d 311 (3d Cir. 1999).

139. E.g., Stephens v. Hayes, 374 F. App’x 620, 624 (6th Cir. 2010); Religious Tech Ctr., 971 F.2d at 367.

140. E.g., Bond, 317 F.3d at 394-395; Jartech, Inc., 666 F.2d at 406; Sturgis, 2007 WL 4247634, at $* 2$.

141. See infra text accompanying notes 206-241 for a discussion of the use of copyrighted works as evidence in quasi-judicial and judicial proceedings. Professor Samuelson categorizes the use of copyrighted works in quasi-judicial and judicial proceedings as one of several "foreseeable uses” that Congress identified could merit fair use protection. Samuelson, supra note 91, at 258788. The policies that underlie this use are "truth telling" and "truth-seeking." Id. at 2546.

142. The judges in Schwegman and Winstead discussed the defendants' use of the works as transformative use. Am. Inst. of Physics v. Winstead PC, No. 3:12-cv-1230-M, 2013 WL 6242843, at *5 (N.D. Tex. Dec. 3, 2013); Am. Inst. of Physics v. Schwegman, Lundberg \& Woessner, P.A., No. 12-528 (RHK/JJK), at 24-25 (D. Minn. July 30, 2013), adopted by 2013 WL 4666330 (D. Minn. Aug. 30, 2013). This discussion is not typical in cases involving use of copyrighted works in quasi-judicial and judicial proceedings. While judges discuss the fair use factors in these cases, they often do not discuss transformative use. See, e.g., Bond, 317 F.3d at 394-95; Jartech, Inc., 666 F.2d at 406-07; Sturgis, 2007 WL 4247634, at *2. Some decisions were issued before Campbell, but the decisions after Campbell also fall into this category. See, e.g., Bond, 317 F.3d at 394-95 (discussing factors only and decided after Campbell); Jartech, Inc., 666 F.2d at 406-07 (discussing factors only and decided before Campbell). The opinions, however, do discuss the purpose for the use. See, e.g., Bond, 317 F.3d at 394-95; Jartech, Inc., 666 F.2d at 406-07; Sturgis, 2007 WL 4247634, at *2. In these cases, the defendants have not altered the original work. See, e.g., Bond, 317 F.3d at 396; Jartech, Inc., 666 F.2d at 406-07; Sturgis, 2007 WL 4247634, at *2. Most decisions focus on the strong support for the use of works in judicial proceedings and do not consider the lack of alteration. See infra text accompanying notes 219-242.

143. Samuelson, supra note 91, at 2542. 
awareness” of how to analyze the statutory factors in a particular case. ${ }^{144}$ This analysis focuses on policy and the societal benefits of the use rather than simply on a categorical fit or a designation of transformativeness. ${ }^{145}$

\section{Purpose and Fourth Factor Analysis}

An understanding of the underlying policy and social benefits of a use can become critical when considering the fourth factor, particularly if a court determines that the use is not "transformative" due to a lack of alteration in the work. Identifying a purpose that courts often recognize as fair use may be inadequate once a court considers the fourth-factor analysis.

While Judge Leval referred to the first factor as "the soul of fair use," 146 he also noted "the close interdependence of the first and fourth factors." 147 The fourth factor addresses "the effect of the use upon the potential market for or value of the copyrighted work." ${ }^{148}$ This evaluation focuses on whether the defendant's use substitutes for the original work and "usurps the market of the original." 149 The first factor, in Judge Leval's view, focuses on whether the defendant's use transforms the "material into a new purpose or message, distinct from [the] purposes of the original." 150 The more that the secondary use is "for new transformed purposes, the less likely it is that appropriative use will be a substitute for the original."151 There would then be less of an impact on the market for the original. ${ }^{152}$

Whether the defendant's use of the copyrighted work results in a substitution for the original requires a review of the defendant's purpose. In some cases, the court needs to conduct very little additional review of the defendant's purpose beyond the initial analysis under the first factor because there is a lack of market impact. The use of copyrighted works in quasi-judicial and judicial proceedings is a good example of when courts have needed to conduct only limited additional analysis of purpose. In most cases in which defendants used copyrighted works for judicial or quasi-

\footnotetext{
144. Id.

145. Professor Loren has emphasized that courts should focus on how a use promotes the goals of copyright rather than on whether the use is transformative or nontransformative. Lydia Pallas Loren, Redefining the Market Failure Approach to Fair Use in an Era of Copyright Permission Systems, 5 J. INTELL. PROP. L. 1, 31-32 (1997).

146. Leval, supra note 89, at 1116.

147. Pierre N. Leval, Campbell v. Acuff-Rose: Justice Souter's Rescue of Fair Use, 13 CARDOZO ARTS \& ENT. L.J. 19, 22 (1994).

148. 17 U.S.C. § 107(4) (2012).

149. NXIVM Corp. v. Ross Inst., 364 F.3d 471, 481-82 (2d Cir. 2004) (citing Campbell v. Acuff-Rose Music, Inc., 510 U.S. 569, 593 (1994)).

150. Leval, supra note 147, at 22.

151. Id. at 22-23 (emphasis omitted).

152. Id.
} 
judicial proceedings, the fourth factor favored the defendants. ${ }^{153}$ The use of the work in these cases had little or no effect on the market for the work, ${ }^{154}$ if a market even existed. ${ }^{155}$ In the Schwegman and Winstead cases, the judges found that the defendants' use of the articles had no effect on the market for the original articles or journals in which they appeared. ${ }^{156}$ There was also no effect on the incentive of the authors to produce articles. ${ }^{157}$ As in other cases involving the use of copyrighted works as evidence, the lack

153. See Samuelson, supra note 91, at 2596. Professor Samuelson notes that “[i]nvestigatory and litigation uses are, moreover, generally unlikely to harm the market for a work. In view of this, courts should probably presume that investigation and litigation uses of works are fair.” Id. The use of copyrighted works for judicial and quasi-judicial proceedings is for a different purpose unrelated to the original use. Images Audio Visual Prods., Inc. v. Perini Bldg. Co. Inc., 91 F. Supp. 2d 1075, 1081-82 (E.D. Mich. 2000) (citing NiMMER \& NimMER, supra note 136, § 13.05[D][2], at 13-230.14). The exception is when the work was prepared specifically for litigation purposes. See id. at 1082, 1085-86. In that situation, the use is the same and competes in the same market. See id.

154. E.g., Jartech, Inc. v. Clancy, 666 F.2d 403, 407 (9th Cir. 1982). In that case, an investigator surreptitiously recorded parts of films shown in a movie theater. Id. at 405 . The plaintiffs held the copyright for the films. Id. The clips were later used as evidence in a nuisanceabatement proceeding. Id. While there was a market for the films, the use of the clips in no way substituted for the original films or affected the market. Id. at 407.

155. Several cases illustrate the lack of a market for the original work. For example, Denison v. Larkin, 1:14-cv-01470, 2014 U.S. Dist. LEXIS 111902 (N.D. Ill. Aug. 13, 2014) involved the use of copies of portions of an attorney's blog in a disciplinary proceeding. The court, in finding fair use, discussed that the use of the copies was for litigation. Id. at * 14 . There was no evidence of a market and no effect on "any perceived market." Id. at *19.

In Scott v. WorldStarHipHop, Inc., No. 10 Civ 9538(PKC)(RLE), 2011 WL 5082410 (S.D.N.Y. Oct. 25, 2011), the plaintiff, a student, engaged in an altercation in a classroom with two fellow students. $I d$. at * 1 . Another student videotaped the altercation on a cell phone. $I d$. The plaintiff purchased, for one dollar, a copy of the cell phone video recording from the person who made the recording. $I d$. at $* 8$. The plaintiff registered the video and then claimed copyright infringement when the defendants used a copy of the recording as evidence in a disciplinary proceeding. Id. at *2. The court found that there was likely no market for the video. Id. at *8. In Bond v. Blum, 317 F.3d 385 (4th Cir. 2003), the defendants intended to introduce the plaintiff's unpublished manuscript as evidence in a child-custody proceeding. Id. at 393. The plaintiff registered the work for the purpose of prohibiting its use in the proceeding. Id. at 391. There was no evidence that the introduction of the manuscript into evidence would affect its marketability. Id. at 396. The district court noted that the use might perversely increase the value of the work. Id. at 396-97.

These last two cases also illustrate the use of copyright as a tool to control the use of a work in litigation or other proceedings. The primary concern of the plaintiff is not the effect on the market for the work but on stopping the use of the work in a proceeding. See Wendy J. Gordon, Fair Use as Market Failure: A Structural and Economic Analysis of the Betamax Case and Its Predecessors, 82 ColuM. L. REV. 1600, 1634-35 (1982) (discussing market failure when a person's refusal to allow use of a copyright work is for reasons not related to the goals of copyright); see also Stephen McIntyre, Private Rights and Public Wrongs: Fair Use as a Remedy for Private Censorship, 48 GonZ. L. REV. 61, 75-76 (2012).

156. Am. Inst. of Physics v. Winstead PC, No. 3:12-cv-1230-M, 2013 WL 6242843, at *11 (N.D. Tex. Dec. 3, 2013); Am. Inst. of Physics v. Schwegman, Lundberg \& Woessner, P.A., Civil No. 12-528 (RHK/JJK), at 31 (D. Minn. July 30, 2013), adopted by 2013 WL 4666330 (D. Minn. Aug. 30, 2013).

157. Schwegman, at 31 . 
of effect on the market for the original work favored fair use. For most cases involving the use of a copyrighted work as evidence, the inquiry into market effect ends with an assessment that there is no substitution for the original work or usurpation of the market. The basic identification of the defendant's purpose as the use of the work in connection with a quasijudicial or judicial proceeding is enough for the limited fourth-factor analysis.

In Schwegman and Winstead, however, the plaintiffs also argued that they lost fee revenue when the defendants made copies of the articles. ${ }^{158}$ The plaintiffs noted that other patent firms were purchasing licenses through the Copyright Clearance Center, and inferred that the purchases were in connection with patent applications. ${ }^{159}$ The plaintiffs argued that there was "a ready market or means to pay for the use" and that this evidence should weigh "heavily against fair use." 160 In Texaco, the court noted the existence of a "workable market for institutional users to obtain licenses" to produce copies of articles. ${ }^{161}$ Since there was a "ready market," the court determined that Texaco's use was "less fair" and ultimately that plaintiffs had sustained substantial harm due to lost revenue. ${ }^{162}$ The plaintiffs in Schwegman also referenced Princeton University Press $v$. Michigan Document Services, Inc. ${ }^{163}$ in support of the proposition that the existence of a licensing market and "the potential for destruction of this market by widespread circumvention of the plaintiffs' permission fee system [was] enough . . . to negate fair use.”164

In Schwegman and Winstead, the plaintiffs' reliance on the availability of a ready license system with current users to negate fair use demonstrates a continuing effort to focus the fourth-factor analysis primarily, or even solely, on the copyright holder's incentives and rewards. Their focus is on whether the use can be paid for, without considering whether the use should

158. Winstead, 2013 WL 6242843, at *11; Schwegman, at 31-32.

159. Plaintiffs' Objections Pursuant to Fed. R. Civ. P. 72(A) and Local Rule 72.2(B) to the Magistrate Judge's Report and Recommendation Entered July 30, 2013, at 13 (Aug. 13, 2013), Am. Inst. of Physics v. Schwegman, Lundberg \& Woessner, P.A., Civil No. 12-528 (RHK/JJK) (D. Minn. July 30, 2013), adopted by 2013 WL 4666330 (D. Minn. Aug. 30, 2013) (hereinafter Schwegman Plaintiffs' Objections).

160. Id. (quoting Am. Geophysical Union v. Texaco Inc., 60 F.3d 913, 931 (2d Cir. 1994)).

161. Texaco, 60 F.3d at 930. The court also referred to a "viable market for licensing." Id.

162. Id. at 931. Particularly after Texaco, courts have considered not only the effect of the use on the market for the original work but also the loss of potential licensing fees. See Mark A. Lemley, Should a Licensing Market Require Licensing?, 70 LAW \& CONTEMP. PROBS. 185, 189 (2007).

163. Princeton Univ. Press v. Mich. Document Servs., Inc., 99 F.3d 1381 (6th Cir. 1996) (en banc).

164. Schwegman Plaintiffs' Objections, supra note 159, at 13-15 (quoting Princeton Univ. Press, 99 F.3d at 1388) (internal quotation marks omitted). 
be paid for. ${ }^{165}$ Scholars have challenged this view, arguing that fair use can apply even when there is a licensing market available. ${ }^{166}$ Courts have also scrutinized the ready market argument more closely and refused in some cases to weigh the fourth factor against defendants even when licensing was available. ${ }^{167}$ Still, copyright holders persist in developing and promoting licensing systems ${ }^{168}$ and arguing for recognition of these systems in fair use analysis. This continuing persistence fosters uncertainty among users and encourages risk-averse behavior. ${ }^{169}$ If a court fails to find that a use is

165. This statement is based on Matthew Africa's description of the differing approaches taken by the majority and dissent in Texaco: "In effect, the majority asked, 'Can the use be paid for?' By contrast, the dissent asked, 'Should the use be paid for?'” Matthew Africa, Comment, The Misuse of Licensing Evidence in Fair Use Analysis: New Technologies, New Markets, and the Courts, 88 CALIF. L. REV. 1145, 1162 (2000).

166. Wendy J. Gordon, Fair Use Markets: On Weighing Potential License Fees, 79 GEO. WASH. L. REV. 1814, 1820 (2011) ("[I]t is perfectly possible within the rhetoric of markets to make the case for fair use even when licensing revenues for the contested use are physically available ... .”); Wendy J. Gordon \& Daniel Bahls, The Public's Right to Fair Use: Amending Section 107 to Avoid the "Fared Use” Fallacy, 2007 UTAH L. REV. 619, 620 (2007) ("Copyright law needs to make clear that any reproduction . . . can potentially need and deserve fair use, despite the presence of an owner willing to license.”); Loren, supra note 145, at 50 ("The fact that a copyright owner has been able to convince others to pay the fee demanded and therefore now can claim to have a 'workable' permission system should not change the analysis.”); Africa, supra note 165 , at $1148-49$ (" $[\mathrm{I}] \mathrm{t}$ is a mistake to think that just because a use could have been licensed it should have been licensed.”).

167. See, e.g., Bill Graham Archives v. Dorling Kindersley Ltd., 448 F.3d 605, 614-15 (2d Cir. 2006); see also Samuelson, supra note 91, at 2620 (discussing courts' willingness to scrutinize claims for licensing fees).

168. Licensing possibilities include conveniently linked services, such as linking interlibrary loan services with obtaining a license for a copy of an article. See JAMES S. HELlER, PAUL HELlyer \& BENJAMin J. KEELE, THE LiBRARIAN's COPYRIGHT COMPANION 86 (2d ed. 2012) (discussing concerns about the Copyright Clearance Center's "Get It Now" service, which links licensing with an interlibrary loan service used by many libraries). With digital works, the technology exists to track and potentially charge for use on a granular level or per view. See D.R. Jones, Locked Collections: Copyright and the Future of Research Support, 105 LAW LIBR. J. 425, 439-40 (2013) (discussing pay-per-view and other means publishers use to charge for the use of digital works); Loren, supra note 145, at 47-48 n.190 ("Computers give copyright owners the tools to know when someone has accessed a chapter, a page, a paragraph, a sentence, or even a phrase. Computers also allow copyright owners to create systems to monitor those uses and charge the user for increasingly smaller percentages of works.”); Alexandra Alter, Your E-Book Is Reading You, WALL ST. J., http://www.wsj.com/articles/SB1000142405270230487030457749095 0051438304 (last updated July 19, 2012, 3:24 PM ET) (describing the kinds of tracking available for e-books).

169. For a discussion of this user behavior, see Christina Bohannan \& Herbert Hovenkamp, IP and Antitrust: Reformation and Harm, 51 B.C. L. REV. 905, 973-74 (2010); Africa, supra note 165, at 1172-73; see also Gibson, supra note 126, at 884; Loren, supra note 145, at 43. Lawsuits can affect the behavior of not only the defendant but also other similarly situated users. As Professor Loren notes, initial settlements and victories can create uncertainty and fear. Loren, supra note 145, at 43 . When news of the publisher lawsuits against patent law firms first appeared, commentators speculated that the publishers were "making a test-run. . . . If the firms fold[ed] their cards and settle[d]," the publisher would bring lawsuits against larger firms. Jeff John Roberts, John Wiley, Physicists Sue Patent Lawyers over Journals, GIGAOM (Mar. 1, 2012, 4:21 
transformative, then the ready market argument is more viable. Still, the court could find that there is not a means of licensing the defendant's type of use and could determine that the use is a fair use even if it is not transformative. Even if in a particular case a court finds there is no licensing for the defendant's type of use, however, there is the suggestion that if a means of licensing became available, the plaintiff may prevail in a future case. So a use that qualifies as a fair use at one time may no longer be a fair use in the future if licensing becomes available. For example, in Cambridge University Press v. Becker, the plaintiff-publishers argued that there was a licensing system available for excerpts of works that university professors placed for students in an electronic reserves system. ${ }^{170}$ The defendants argued that use of the excerpts was fair use. ${ }^{171}$ After a bench trial, the district court determined that the defendants' use was for non-profit educational purposes, but was non-transformative. ${ }^{172}$ In discussing the fourth factor and the plaintiffs' argument that a means to pay license fees was available, the court favorably quoted Texaco regarding the effect of the availability of a "ready market" on the determination of fair use. ${ }^{173}$ The court noted that the plaintiff-publishers' "right, as owners of the copyrights, to collect fees for use of excerpts from their books ... is a powerful argument countering fair use, which counsels against [the d]efendants' position when excerpts are readily available, in a convenient format, for a reasonable fee, and the fees are not paid." 174 In reviewing each of the allegedly infringing uses, the court determined that for some of the uses there was "a ready market” for licensing the use. ${ }^{175}$ This fact resulted in the

PM), http://gigaom.com/2012/03/01/419-john-wiley-physicists-sue-patent-lawyers-over-journals/. One firm did settle, and the Copyright Clearance Center announced the firm signed a license agreement. Press Release, Copyright Clearance Center, Hovey Williams LLP Signs Copyright Clearance Center's Annual Copyright License (June 28, 2012) (the case terminated on June 25, 2012). After the fair use decisions in two of the cases, however, the publishers dismissed all actions. See supra notes 25-27 and accompanying text.

170. See Cambridge Univ. Press v. Becker, 863 F. Supp. 2d 1190, 1237 (N.D. Ga. 2012), rev'd in part, vacated in part sub nom. Cambridge Univ. Press v. Patton, 769 F.3d 1232 (11th Cir. 2014).

171. Cambridge Univ. Press, 863 F. Supp. 2d at 1203, 1223.

172. Id. at 1224-25, 1232. The district court relied on a statement in a footnote of the Campbell case to determine that the use was nontransformative. Id. at 1225 (quoting Campbell v. Acuff Rose Music, Inc., 510 U.S. 569, 579 n. 11 (1994)).

173. Id. at 1237 (quoting Am. Geophysical Union v. Texaco Inc., 60 F.3d 913, 931 (2d Cir. 1994)).

174. Id. at 1239.

175. See, e.g., id. at 1258-59 (analyzing the use of THE SAGE HANDBOOK OF QUALITATIVE RESEARCH (Norman K. Denzin \& Yvonna S. Lincoln eds., 3d ed. 2005)); id. at 1361-63 (analyzing the use of MichaEl QUiNN PATtON, UtILIZATION-Focused EVALUATION (4th ed. 2008)); see also id. at 1239 (discussing the impact of the availability of licenses on the fourth factor analysis). 
fourth factor analysis "strongly" favoring the plaintiffs in those situations. ${ }^{176}$

The Eleventh Circuit, in reviewing the district court's decision, agreed that the defendants' use was not transformative. ${ }^{177}$ The court also determined that the district court appropriately considered license availability. ${ }^{178}$ The court, however, determined that the district court erred in not giving the fourth factor analysis more weight because "[d]efendants' copying was nontransformative and the threat of market substitution was therefore serious." 179

The discussions of the fourth factor in the district court and Eleventh Circuit opinions in this case suggest that the "right ... to collect fees" can overpower other factors, such as educational and nonprofit use of works, particularly if the court finds that the use is nontransformative. ${ }^{180}$ In predicting possible fair use outcomes, simply focusing on the purpose of the defendant's use may not be enough to overcome the plaintiff's proof of a licensing market. The defendants should urge the court to apply an analysis of the fourth factor that considers not just whether there is a way to pay for the use, but whether the defendant should pay. ${ }^{181}$

In Schwegman and Winstead, the judges rejected the plaintiffs' ready market argument that the loss of licensing fees supported a denial of fair use. ${ }^{182}$ Both judges considered the defendants' purpose in analyzing the fourth factor. In Schwegman, Judge Keyes, relying on Bill Graham Archives v. Dorling Kindersley Ltd., ${ }^{183}$ provided a lengthy discussion of the close relationship between the defendants' purpose and the fourth factor. ${ }^{184}$ As in Bill Graham Archives, the availability of licensing did not dictate that the defendants had to pay. ${ }^{185}$ Also, since the defendants' use was within a

176. Id. at 1259, 1362.

177. Cambridge Univ. Press v. Patton, 769 F.3d 1232, 1262 (11th Cir. 2014).

178. Id. at 1279 .

179. Id. at 1281. The Eleventh Circuit found that the district court conducted a mechanistic review of the four factors, giving each factor equal weight. Id. at 1260, 1283. For this and other reasons, the Eleventh Circuit reversed and remanded the district court's decision. Id. at 1283-84.

180. Professor Jaszi proposes that educational institutions should focus on describing the transformativeness of educational uses. Peter Jaszi, Fair Use and Education: The Way Forward, 25 L. \& LIT. 33, 40, 45 (2013). This is solid advice, since a determination that a use is transformative changes a court's fair use analysis. If a court finds a use not to be transformative, the question is how can a defendant defeat an argument that there is a ready market and means to collect fees.

181. See discussion infra Part III.D.

182. Am. Inst. of Physics v. Winstead PC, Civil Action No. 3:12-cv-1230-M, 2013 WL 6242843, at $* 12$ (N.D. Tex. Dec. 3, 2013); Am. Inst. of Physics v. Schwegman, Lundberg \& Woessner, P.A., Civil No. 12-528 (RHK/JJK), at 31-33 (D. Minn. July 30, 2013), adopted by 2013 WL 4666330 (D. Minn. Aug. 30, 2013).

183. Bill Graham Archives v. Dorling Kindersley Ltd., 448 F.3d 605 (2d Cir. 2006).

184. Schwegman, at 33-34.

185. Id. at 34 . 
"transformative market," the loss of any fees did not result in market harm to the plaintiffs. ${ }^{186}$ In his summary analysis of the four factors, Judge Keyes noted that the defendants' use provided a public benefit that promoted the progress of science and useful arts. ${ }^{187}$ While Judge Lynn in Winstead also discussed the defendants' transformative purpose in analyzing the fourth factor, she found that "[t]he determinative issue, however, [was] the public benefit associated with [the] defendants' use of NPL copies." 188 This benefit outweighed any potential gain to the plaintiffs from fees. ${ }^{189}$

\section{Fair Use Markets}

\section{Definition of a Fair Use Market}

The types of fourth-factor analysis, considerations, and results in cases like Schwegman and Winstead evoke Professor Gordon's discussion of the concept of "fair use markets." 190 This concept provides a means to consider whether a defendant should pay a fee if a licensing system exists. ${ }^{191}$ The Second Circuit stated the concept in Castle Rock Entertainment, Inc. v. Carol Publishing Group, Inc., ${ }^{192}$ and applied it in Bill Graham Archives. ${ }^{193}$ A fair use market is one in which the availability of licensing will not preclude fair use. ${ }^{194}$ Further, in some circumstances a court might not consider the availability of licensing at all in determining the fourth factor. ${ }^{195}$ The Second Circuit in Bill Graham Archives focused on

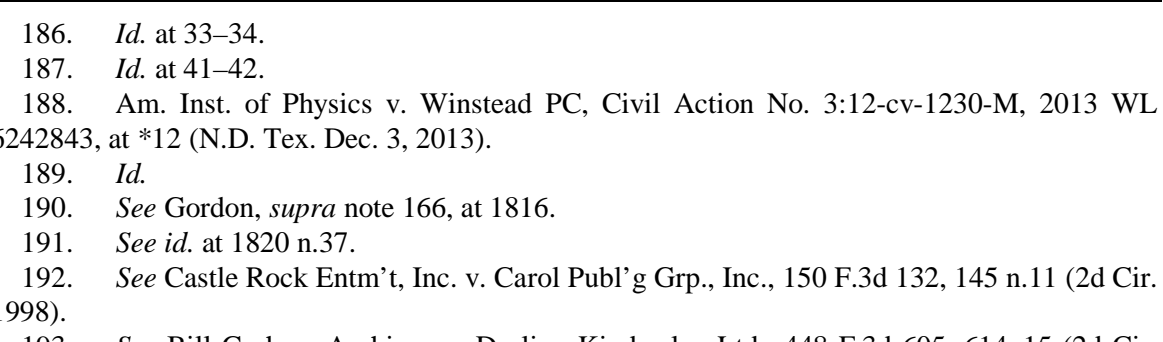

193. See Bill Graham Archives v. Dorling Kindersley Ltd., 448 F.3d 605, 614-15 (2d Cir. 2006). The court stated that "a copyright holder cannot prevent others from entering fair use markets merely 'by developing or licensing a market for parody, news reporting, educational or other transformative uses of its own creative work. . . . [C]opyright owners may not preempt exploitation of transformative markets."” Id. (second \& third alteration in original) (quoting Castle Rock Entm't, Inc., 150 F.3d at 145 n.11). The district court in its opinion in Bill Graham Archives also quoted Castle Rock. Bill Graham Archives, LLC v. Dorling Kindersley Ltd., 386 F. Supp. 2d 324, 328, 330, 332 (S.D.N.Y. 2005), aff'd sub nom. Bill Graham Archives v. Dorling Kindersley Ltd., 448 F.3d 605 (2d Cir. 2006) (quoting Castle Rock Entm't Inc., 150 F.3d at 136, 142, 145 \& n.11). The district court elaborated that the reasoning supporting the Second Circuit's statement was that otherwise "a copyright holder could prevent the fourth factor from ever supporting fair use by licensing parodies, criticisms, or other uses and arguing that any such use that is not licensed invades on a ‘traditional' market.” Bill Graham Archives, LLC, 386 F. Supp. 2d at 332.

194. Gordon, supra note 166, at 1841.

195. Id. at 1841 (discussing the Second Circuit's holdings in Bill Graham Archives). 
transformative use as the criterion for a fair use market. ${ }^{196}$ Professor Gordon finds this criterion "problematic" and "incomplete" due to the continuing lack of clarity and definition of the term transformative and its application. ${ }^{197}$ She redefines a fair use market as "a market in which we cannot rely on the decisions of copyright holders to take into account all the relevant values and interests, or as a setting where available nonmarket interactions and institutions are likely to do a better job in advancing [p]rogress.” 198 This definition covers transformative and nontransformative uses. ${ }^{199}$ The removal of transformativeness as a criterion is important because it forces a deeper analysis and review of the defendant's use. The transformative label is not intended to offer a shield, but its absence is no longer a determinant of the strength of the defendant's fair use argument. ${ }^{200}$ The analysis to determine the existence of a fair use market requires a review of the defendant's purpose, not just whether the purpose is different or even whether it adds something new. The review focuses on the values, policies, and reasoning underlying the use. This deeper analysis addresses the calls of scholars for a broader, more balanced analysis of the fourth factor. $^{201}$

\section{Determination of a Fair Use Market}

The determination of a fair use market is part of the fourth-factor analysis. The need for this determination arises if the plaintiff claims the loss of fees from licensing. Professor Gordon offers examples of uses that could fit within her definition of a fair use market. ${ }^{202}$ Uses of copyrighted works in quasi-judicial and judicial proceedings epitomize uses that should be within a fair use market. These uses "employ copyrighted works as factual evidence,” which is one of Professor Gordon's examples. ${ }^{203}$ The use of copyrighted works in the patent application process fits within these uses.

An analysis of the use of copyrighted works in legal proceedings, including the patent application process, illustrates the determination of a

\footnotetext{
196. See id. at 1842.

197. Id. at $1831 \mathrm{n} .98,1842$

198. Id. at 1842 (footnote omitted) (internal quotation marks omitted).

199. Id. at 1842; see also id. at $1831 \mathrm{n} .98$ ("[T]ransformativeness is incomplete as a criterion for disregarding foregone license fees, whether understood as alteration of content, or as alteration of purpose. I suggest that there are some bases for disregarding license fees that have nothing to do with transformativeness under either definition.”).

200. A determination of whether a non-altering use is transformative can still be uncertain. See Swatch Grp. Mgmt. Servs. Ltd. v. Bloomberg L.P., 742 F.3d 17, 28 (2d Cir.), amended and superseded by 756 F.3d 73 (2nd Cir. 2014). See discussion of the Swatch opinions supra note 96.

201. See, e.g., Loren, supra note 145, at 56.

202. Gordon, supra note 166, at 1843-44.

203. See id. at 1843-44.
} 
fair use market. ${ }^{204}$ As part of any fair use analysis, the court identifies the defendant's use and "the purpose and character of the use." 205 A review of the defendant's use of a copyrighted work is a key part of the analysis to determine a fair use market. The court will build upon this identification to determine if the context for this use possesses the characteristics of a fair use market.

Copyrighted works in legal proceedings may be used as factual evidence. While the character of the work as originally used was expressive, the character of the use in a legal proceeding is factual. ${ }^{206}$ The use of the work is solely for the "evidentiary value of its content." ${ }^{207}$ The purpose of using the work as evidence in a legal proceeding is to provide relevant information to the fact finder in the proceeding. ${ }^{208}$ In the patent application process, submitted articles and other documents are for the PTO's use. The character of the use of copyrighted works in the patent application process is also factual rather than expressive. The PTO uses the submitted works "not for their expressive content, but as evidence relating to the factual question of whether an invention is novel or non-obvious in view of the prior art as of a certain date.”209 In Winstead, Judge Lynn adopted an analogy the PTO had used in its brief, likening the defendant law firm's use of the articles to the use of hearsay. ${ }^{210}$ The defendants were not interested in the truth of the information in the articles; they were instead interested in the existence and disclosure of the information at the time of publication, regardless of whether it was true or not. ${ }^{211}$ In the patent application process, patent applicants have a duty to disclose "all information known to that individual to be material to patentability." ${ }^{212}$ The

204. While Professor Gordon identifies these examples, she does not provide an analysis of them. This illustration provides the details of the analysis for one example.

205. 17 U.S.C. \& 107(1) (2012).

206. See Wendy Gordon, Reality as Artifact: From Feist to Fair Use, LAW \& CONTEMP. PROBS. 93, 96-98 (1992) (discussing the use of expressive copyrighted works as facts); see also Gordon, supra note 166, at 1852 n.209 (noting how the use of a copyrighted work in a legal proceeding is as a fact rather than an expressive work).

207. E.g., Bond v. Blum, 317 F.3d 385, 395 (4th Cir. 2003).

208. See, e.g., id.

209. Memorandum from Bernard J. Knight, Jr., Gen. Counsel, U.S. Patent \& Trademark Office, at 3 (Jan. 19, 2012). The focus on the availability of the article as of a certain date highlights the importance of the fact of the prior existence of the article at a certain time. See Gordon, supra note 206, at 97 \& n.22 (discussing that in the use of an expressive copyrighted work as fact, the prior existence of the work "in a particular context" is an essential part of the secondary user's message).

210. Am. Inst. of Physics v. Winstead PC, Civil Action No. 3:12-cv-1230-M, 2013 WL 6242843, at *5 (N.D. Tex. Dec. 3, 2013).

211. Id. at *5; see Gordon, supra note 206, at 98-99 n.26 (comparing the factual use of copyrighted works with the use of hearsay).

212. 37 C.F.R. § 1.56(a) (2013). 
filing of this material information relates directly to the patent examiner's determination of patentability. ${ }^{213}$

In cases involving the use of copyrighted works in legal proceedings and the use of copyrighted works in the patent application process, the defendant's use is different in character and purpose from the plaintiff's. ${ }^{214}$ Identifying this different character and purpose supports a finding of fair use under the first factor. The finding of this different character and purpose also favors a finding under the fourth factor that there is no substitute for the original work and little or no impact on the market for the original work (if one exists). ${ }^{215}$ In Winstead and Schwegman, however, the plaintiffs claimed the loss of fee revenue due to the defendants' failure to pay when there was an existing payment system available for the defendants' type of use. ${ }^{216}$ If future plaintiffs make this claim, the court needs to perform a deeper examination of the purpose (reason) for the defendant's use. ${ }^{217}$ The analysis extends to consider the broader context of the defendant's use, and whether the market would take into account societal values and benefits relating to the defendant's use. ${ }^{218}$ The goal is to determine if this use is within a fair use market. If it is, then the court can find fair use despite the existence of a ready market for the payment of usage fees.

213. Christopher A. Cotropia, Modernizing Patent Law's Inequitable Conduct Doctrine, 24 BERKELEY TECH. L.J. 723, 752 (2009).

214. For example, copied excerpts from films that city officials presented in a nuisanceabatement proceeding were not used for entertainment (i.e., the original purpose) but as factual evidence that the showing of the films violated a city ordinance. Jartech, Inc. v. Clancy, 666 F.2d 403, 407 (9th Cir. 1982)

215. See supra notes 154-155.

216. Winstead, 2013 WL 6242843, at *5; Am. Inst. of Physics v. Schwegman, Lundberg \& Woessner, P.A., Civil No. 12-528 (RHK/JJK), at 31-32 (D. Minn. July 30, 2013), adopted by 2013 WL 4666330 (D. Minn. Aug. 30, 2013).

217. Analysis in cases involving the use of copyrighted works in legal proceedings do not usually go beyond noting that this type of use generally favors fair use. Additional analysis notes that the purpose of the use is for evidence. See supra notes 138-139 and accompanying text. The suggested analysis in this Article explores the principles underlying the purpose for the use to determine whether the use is within a fair use market.

218. Under the Second Circuit's application of the fair use market concept, the transformativeness of the defendant's use provides the basis for the fair use market. Judge Keyes in Schwegman relied on Bill Graham Archives to determine that the plaintiffs could not show impairment to a "traditional, as opposed to a transformative market" and could therefore not claim licensing fees even though they had identified a payment system. See Schwegman, at 34 (citing Bill Graham Archives v. Dorling Kindersley Ltd., 448 F.3d 605, 614 (2d Cir. 2006)). Under Professor Gordon's analysis, the "transformative" label would not be determinative of whether there is a fair use market. Gordon, supra note 166, at 1842. The analysis would extend to consider the broader context for the defendant's use and whether the market would take into account societal values and benefits relating to the defendant's use. Id. at 1843-44. 


\section{a. Considerations in the Immediate Context}

In determining a fair use market, the first consideration is the effects on the immediate proceeding if the copyright holder withholds or limits access to a copyrighted work. A copyright holder has the right to require consent (including payment) for use of a work and may refuse consent for use of a work. ${ }^{219}$ While the copyright holder has this right, the refusal or limitation of access in the context of a legal proceeding could result in the inability to provide all relevant information to the fact finder. The copyright holder may have the only copy of the work or may control all available copies. The party who needs to use the work as evidence could have no alternative means to obtain a copy of the work. In a particular proceeding, allowing a copyright holder to exercise control over a work could thwart the ability of the fact finder to make an accurate determination due to lack of access to relevant evidence. As Professor Weinstein emphasized, "The fundamental condition for enhancing the possibility of accurate fact finding is that as much of the available relevant information as possible be placed before the trier." ${ }^{220}$ Parties in a legal proceeding require the ability to review and present evidence. ${ }^{221}$ There is also the concern that a copyright holder may deny consent in order to block or control the use of the work for its evidentiary value rather than out of any monetary concerns. ${ }^{222}$ Allowing a copyright holder to control the use of a work in a legal proceeding raises concerns about the diminished ability to reach a fair determination in the proceeding. This situation suggests that society should not rely on the

219. See Gordon, supra note 155, at 1634 (“[M]arkets can function only if owners have a right to say 'no' as well as 'yes.'”).

220. Jack B. Weinstein, Some Difficulties in Devising Rules for Determining Truth in Judicial Trials, 66 ColuM. L. REV. 223, 243 (1966).

221. See Images Audio Visual Prods., Inc. v. Perini Bldg. Co., 91 F. Supp. 2d 1075, 1081, 1086 (E.D. Mich. 2000) ("[C]opyright protection must yield to the need to present a complete evidentiary record.”). This need extends to the review and use of materials in connection with legal proceedings even though they are not used as evidence. See, e.g., cases cited supra note 138.

222. The case of Grundberg v. Upjohn Co. illustrates how a copyright holder could attempt to block the use of copyrighted works to limit or prevent use in a legal proceeding rather than to protect a market interest. Grundberg v. Upjohn Co., 137 F.R.D. 372, 388 (D. Utah 1991). In Grundberg, a products liability case, the defendant company attempted to block the use of company documents by registering a copyright for those documents. Id. The documents had been marked confidential, but the plaintiffs sought to remove the confidentiality. Id. at 378. The company sued the plaintiffs for copyright infringement. Id. The court noted that the company was attempting "to thwart accessibility to the public of information contained in documents which may be offered and admitted into evidence in court proceedings.” Id. at 388 . The court held that the company could not assert a copyright interest "to impede or prevent the free use and accessibility of such documents in the context of this litigation.” Id. For other examples of attempts to prevent the use of copyrighted works in a legal proceeding, see cases cited supra note 155. 
decisions of copyright holders to determine whether the defendant can use the work. ${ }^{223}$

In the patent application process, copyright holders also have the right to control the use of a work by requiring a fee or denying access. Allowing the copyright holder to control the use of a work in this process, however, can thwart the ability of a patent examiner to review a complete record. The presented materials possess a unique evidentiary value for the determination of patentability. Patent examiners may not have access to these works, and if the applicants are stymied in providing the relevant materials, the examiners will have no alternative method to review these works. ${ }^{224}$ Additionally, the examiner will probably not have the time to seek this information. ${ }^{225}$ Examiners rely on the applicants to provide the relevant information since the applicants have the best knowledge of the invention and can better identify prior art. ${ }^{226}$ The applicants also have a duty to present all material documentation, and requiring these applicants to identify copyright holders and obtain permissions can interfere with fulfilling this duty. ${ }^{227}$

\section{b. Considerations in the Broader Context}

The determination of a fair use market also considers how allowing a copyright holder to control copyrighted works affects societal values and interests in a broader context for the use. A copyright holder's control over the use of a work in a legal proceeding has a wider impact than just on the immediate proceeding. The use of copyrighted works as evidence supports the policies of "truth telling" and "truth seeking." 228 There is an "important

223. An example of other situations in which copyright holders might attempt to suppress or control use of copyrighted works for nonmonetary reasons is when the defendant uses the work for criticism or parody. These situations also raise concerns about deferring to the copyright holder. See Gordon, supra note 155, at 1632-57; Wendy J. Gordon, Excuse and Justification in the Law of Fair Use: Transaction Costs Have Always Been Only Part of the Story, $50 \mathrm{~J}$. COPYRIGHT SOC'Y U.S.A. 149, 186 (2003); Wendy J. Gordon, Toward a Jurisprudence of Benefits: The Norms of Copyright and the Problem of Private Censorship, 57 U. CHI. L. REV. 1009, 1042-43 (1990).

224. Cotropia, supra note 213, at 753-54.

225. Id. at 750 .

226. Id. at 753-54.

227. See Am. Inst. of Physics v. Winstead PC, Civil Action No. 3:12-cv-1230-M, 2013 WL 6242843, at *2 (N.D. Tex. Dec. 3, 2013).

228. Samuelson, supra note 91, at 2546, 2595 (quoting Images Audio Visual Prods., Inc. v. Perini Bldg. Co., 91 F. Supp. 2d 1075, 1086 (E.D. Mich. 2000)). The court in Perini noted "that copyright protection must yield to the need to present a complete evidentiary record.” Perini, 91 F. Supp. 2d at 1086; see also FED. R. EVID. 102 (noting that the rules of evidence, which provide for the submission of relevant information, facilitate "ascertaining the truth and securing a just determination”); Weinstein, supra note 220, at 243 ("Truth finding must be a central purpose whatever the tribunal.”). 
societal interest in having evidence before the [finder of fact]." ${ }^{229}$ This societal interest in litigation is not just concern for the resolution of individual disputes. Litigation is conducted for the ultimate benefit of society in supporting "the cause of justice." 230 Limitations on the availability of evidence could create barriers that ultimately jeopardize this policy. ${ }^{231}$ The self-interest of a copyright holder in withholding access to a copyrighted work or seeking remuneration does not account for this societal value. Professor Loren emphasized that courts often focus their economic analysis only on the effects on the parties to a lawsuit. ${ }^{232}$ They fail to acknowledge external and nonmonetizable societal benefits. ${ }^{233}$ Reducing barriers to the presentation of relevant evidence promotes not only truth finding but also confidence in the legal system. ${ }^{234}$ In cases involving the use of copyrighted works as evidence, the market cannot be relied upon to take into account these important, nonmonetizable values. ${ }^{235}$

In the patent application process, plaintiffs seek fees for use of copies and are not trying to manipulate the system. Deferring to these plaintiffs' interests, however, would affect the public interest in the patent system. ${ }^{236}$ In both Schwegman and Winstead, the judges discussed the importance of supporting the patent system and how ceding to licensing demands could affect its ability to function properly. ${ }^{237}$ In analyzing the fourth factor, both judges recognized the importance of a public benefit and refused to let the

229. Bond v. Blum, 317 F.3d 385, 396 (4th Cir. 2003).

230. Charles Frederic Chamberlayne, The Modern Law of Evidence and Its Purpose, 42 AM. L. REV. 757, 765 (1908).

231. Id. at 772 ("Society has a transcendent interest in the ascertainment of truth and should remove all barriers across the path of its tribunals in reaching it . ...”).

232. Loren, supra note 145, at 53-54.

233. Id.

234. See David P. Leonard, The Use of Character to Prove Conduct: Rationality and Catharsis in the Law of Evidence, 58 U. COLO. L. REV. 1, 39 (1986); Weinstein, supra note 220, at 241 .

235. Loren, supra note 145, at 26 (citing Gordon, supra note 155, at 1630-31). While the use of evidence in legal proceedings may not necessarily further creativity, copyright law can support other important societal values. The copyright monopoly cannot override important policies such as those that support our judicial system. Fair use supports more than new creations; it supports policies and systems of societal value. Id.

236. Professor Gordon discussed how copyright holders can legitimately refuse to allow the use of works to protect their monetary interests. Gordon, supra note 155, at 1634. Addressing external or nonmonetizable interests, however, can outweigh this right. See id. at 1634-35, 1634 n.192 (identifying Time, Inc. v. Bernard Geis Assocs., 293 F. Supp. 130 (S.D.N.Y. 1968) as a case involving external or nonmonetizable interests that outweighed a plaintiff's legitimate monetary interest).

237. Am. Inst. of Physics v. Winstead PC, Civil Action No. 3:12-cv-1230-M, 2013 WL 6242843, at*10-12 (N.D. Tex. Dec. 3, 2013); Am. Inst. of Physics v. Schwegman, Lundberg \& Woessner, P.A., Civil No. 12-528 (RHK/JJK), at 41-42 (D. Minn. July 30, 2013), adopted by 2013 WL 4666330 (D. Minn. Aug. 30, 2013). 
plaintiffs' ready market argument support a denial of fair use. ${ }^{238}$ Judge Keyes in Schwegman noted that the defendants' copying of articles and use of the copies "facilitate[d] the complete disclosure required in the patentapplication process, assist[ed] patent examiners in determining whether applications for patent protection should be granted, and, consequently, fulfill[ed] the very same purpose of promoting science and the arts that the Copyright Act was intended to accomplish.”239 He discussed the use of copies in patent applications fulfilled a public benefit much like the use of copyrighted materials in the activities listed in the preamble to $\S 107 .{ }^{240}$ Judge Lynn in Winstead stated that the determinative issue in the fourthfactor analysis was the public benefit in the form of "minimiz[ing] excessive costs in patent applications and maximiz[ing] the accuracy of the patent process.”241 This benefit outweighed any potential gain to the plaintiffs from fees. ${ }^{242}$

\section{c. Summary: Determination of a Fair Use Market}

An examination of the use of copyrighted works in legal proceedings, including the patent application process, demonstrates how a closer and more in-depth analysis of the purpose and character of a defendant's use can result in the identification of a fair use market. The negative effects of granting copyright holders control in both the immediate and broader context of these uses raise concerns that the market cannot address all relevant values and interests. Identification of a fair use market supports strong underlying societal interests. The further analysis of the use in these cases also demonstrates that it is possible to establish the existence of a fair use market without relying on a "transformative" label for the use. ${ }^{243}$ The

238. Winstead, 2013 WL 6242843, at *12; Schwegman, 41-42.

239. Schwegman, at 41-42.

240. Id. at 41; see also Loren, supra note 145, at 49 (noting that the uses listed in the preamble to $\S 107$ support external societal benefits).

241. Winstead, $2013 \mathrm{WL} 6242843$, at *12. As part of her analysis of the first factor, Judge Lynn also considered the public benefit of the defendants' copying. Id. at *4, *8 (citing Campbell v. Acuff-Rose Music, Inc., 510 U.S. 569, 578 (1994); Sega Enters. Ltd. v. Accolade, Inc., 977 F.2d 1510, 1523 (9th Cir. 1992) ("Public benefit need not be direct or tangible, but may arise because the challenged use serves a public interest.”)). Judge Lynn determined that the filing of NPL in patent cases assists the PTO examiners in "more efficiently" determining patentability. Winstead, 2013 WL 6242843, at *9 (citing Memorandum in Support of Motion to Intervene of the United States Patent and Trademark Office at 13, Am. Inst. of Physics v. Winstead, No. 3:12-cv01230-M, 2013 WL 6242843 (N.D. Tex. Dec. 3, 2013)). Requiring attorneys to get a license for every article they need to review would "slow[] down the patent application process" and could result in "erroneous patentability decisions." $I d$.

242. Winstead, 2013 WL 6242843, at *11, *12.

243. If the use in Schwegman and Winstead had not been transformative, it still would have been possible to demonstrate the existence of a fair use market. See discussion supra Part III.D.2.b. 
determination that the defendant's use is within a fair use market allows for the coexistence of fair use with a ready market for the payment of fees. ${ }^{244}$

\section{CONCLUSION}

The recent decisions in the Schwegman and Winstead cases affirm the fair use of copies of non-altered copyrighted works as part of the patent application process, including copies for clients and internal use. The judges in these cases determined that this use was transformative without any alteration in content due to the different purpose for the use. ${ }^{245}$ These decisions follow the trend in fair use analysis to identify non-altered use of copyrighted works as transformative if the purpose for the use is different from the original. Despite this trend, there is still uncertainty in the interpretation of "transformative." Anyone seeking predictability in fair use analysis should not rely solely on a determination of transformative use.

Users seeking fair use treatment should consider how their use fits into identified groups or clusters of similar cases. Professor Samuelson's clusters are useful for guidance. ${ }^{246}$ These clusters represent groups of uses that have a common character and purpose, and that courts have regularly identified as fair use. ${ }^{247}$ The identified policy clusters also offer underlying policy and reasoning for the use. ${ }^{248}$ Readiness to discuss the underlying policy and benefits of a use is essential when a plaintiff asserts that there is a ready market to collect fees for use.

The fair use market concept provides an excellent means of identifying when a defendant can use a copyrighted work without permission, even though there is a system available for the payment of fees to the copyright holder. The use of copyrighted works in legal proceedings, including the patent application process, offers a model for the determination of a fair use market. In this model, based on Professor Gordon's definition of a fair use market, the determination of a fair use market must involve a deeper analysis of the use and its character and purpose. This inquiry explores the underlying effects of copyright-holder control in both the immediate and

\footnotetext{
244. The court still takes into consideration the existence of foregone license fees and the availability of a means to make payments. Under the holding in Bill Graham Archives, a court can also refrain from considering foregone licensing fees in the fourth-factor analysis if a fair use market exists for certain kinds of uses. See Gordon, supra note 166, at 1841, 1844-54 (discussing this holding in Bill Graham Archives and identifying uses that might merit such treatment). The use of copyrighted works as factual evidence in legal proceedings could also fit into this category. See id. at 1852 n.209, 1853 (nonmonetizable interests). A discussion of this possibility is beyond the scope of the current Article.

245. Winstead, 2013 WL 6242843, at *6; Schwegman, at 33-34.

246. See Samuelson, supra note 91, at 2544-45.

247. Id. at 2542 .

248. Id.
} 
broader context of the use. This deeper analysis also considers societal benefits of the use. Under this approach, a court can find fair use even if it determines that the use is not transformative. As the model illustrates, the determination of a fair use market can provide recognition of when a user should not pay for the use, even if there is a means to pay. 